\title{
Problems of State Efficiency and Terrorism in North Africa
}

\author{
Habil. Maria Bordás \\ National University of Public Service, Budapest, Hungary
}

\begin{abstract}
The study examines how the state inefficiency in North Africa has led to the increase of the terrorism in these countries. The reasons of the terrorism in these countries are fairly complex, cannot be described with only one feature, like the Islamic fundamentalism, but much too far related to state efficiency issues. The study will analyze the segments of the state inefficiency that are typical as the reasons for the terrorism in North Africa, but will examine the countries one by one, as well. That is, there are general phenomena which are closely related to the terrorism, there are special features in these countries, too, which cannot be described with the general tendencies in themselves. Finally, the conclusion will be made on the strategies in developing the efficiency of the state which could serve as a tool in the counter-terrorism of North African countries. The standpoint of the study is that terrorism cannot be defeated by the military itself, but by a complex development of the state functions which are capable to eliminate the roots of the terrorism.
\end{abstract}

Keywords: terrorism, North Africa, state efficiency, Islamic fundamentalism, good governance

The aim of the study is to shed light on how the state inefficiency in North Africa has led to the increase of the terrorism in these countries. The terrorist attack in the gas plant in Algeria and the armed conflict caused by the Tuareg tribe in Mali-both in 2013, called the attention to the fact that North African countries have increasingly served as a safe haven for the terrorist groups.

Terrorism in North Africa has special features compared with that of it in the Middle East, although, there are certain similarities, of course. The reasons of the terrorism in the North African countries are fairly complex, cannot be described with only one feature, like the Islamic fundamentalism, but much too far related to state efficiency issues.

The study will analyze the segments of the state inefficiency that are typical as the reason for the terrorism in North Africa, but will examine the countries one by one, as well. This is because there are general phenomena which are closely related to the terrorism, but besides, there are special features in these countries, too, which cannot be described with the general tendencies in themselves.

It should be noted too that the terrorism has special features in the North African countries, to compare them with the Middle East. The most important difference is that most of the terrorist groups in North Africa have been Al-Qaeda affiliates, but they are reluctant to implement terrorist attacks at global level, "just” in North Africa, and they are, however, jihadists, do not want to establish the World Caliphate, "just" to infiltrate in the state authorities here.

Finally, the conclusion will be made on the strategies in developing the efficiency of the state which could

Corresponding author: Habil. Maria Bordás, Ph.D., Professor of Law, National University of Public Service; research fields: state efficiency, good governance, terrorism, and failing states. E-mail: maria.bordas@t-online.hu. 
serve as a tool in the counter-terrorism of North African countries. The starting point of the study is that terrorism cannot be defeated by the military itself, but by a complex development of the state functions which are capable to eliminate the roots of the terrorism. It is not hopeless that even many consider it fairly seems to be so.

\section{Meaning and Relevance of State Efficiency in North Africa}

The question of the efficient state has been one of the most often debated issues in Europe and the US since the 1980s.

The "neoliberal economic policy" which was rooted in the US in the second part of the 1970s, was transformed to the practice in the form of "new public management". This latter one had three segments: establishing more market and less state, using management means in the public sector, and applying business principles. It meant that the state was expected to withdraw from the market, in other words, to intervene in a less manner in the economic processes, and principles of market mechanisms, such as private ownership, market competition, profit motivation, more opportunity for the customer choice, etc., were emphasized.

The European public administrators sought for the answer to the question, if the new public management could be applied in the centralized, law-governed European public administration systems, in the so-called "Weberian model". By the end of the 1990s, it became quite clear in Europe that the principles of the neoliberal economic policy could not be applied in the public sector in the American way, although some elements such as public policy in the quality legislation, e-government in the administrative jurisdiction, public leadership in the public service, privatization of certain public services, etc., were introduced. The neoliberal economic policy could never be changed, however, the solidarity-based welfare system in Europe to a business view-oriented that developed in the American model.

The issue of the state efficiency in the developed Western countries had another aspect, as well, which was identified as the requirements of good governance during the 2000s. The world economic crises in 2007 called the attention to the importance of the state intervention in the economy, i.e., to solve certain market failures such as to strengthen the stock and money market supervision. As a result, the neoliberal economic policy was accused with the economic problems, and instead of the neo-liberalism, an expectation had been seen toward a strong state that can solve economic and social problems in a highly efficient way.

The good governance includes several requirements toward the government, e.g., predictability, accountability, transparency, accessibility, public interest-orientation, professionalism, etc. The relationship between the politics and the public administration was rethought by the political and administrative scientists, too, e.g., the system of checks and balances, the role of the interest groups (lobbies), the majority-based democracy, the decision-making process of the government, the formulation of the public interest, the issues of the so-called "spoil system", etc., and called the attention to the different solutions between the European and US state systems.

The aforementioned issues of the state efficiency arose in the European post-communist countries as a challenge to establish a market-oriented economy, instead of the former communist bureaucratic economic administration, and also, to build a democratic state system to change the former dictatorial, one-party based regimes. These goals could not be achieved without difficulties: In the lack of democratic traditions, the post-communist countries in Central and Eastern Europe had to face only a slow evolution of a well-operating market economy and governance based on democratic values. Efficiency requirements do not have such a refined meaning here, like in the developed Western countries, the goal seems much rather to achieve just the basic institutions of the Western-type democracies. 
When the study is trying to analyze in the North African countries, how the state inefficiency has led to the escalation of the terrorism, it is needed to identify what elements of the state efficiency will be examined. That is, in a weak or failed state, there would make just little sense to discuss the characteristics of the efficient state evolved in the developed Western countries. Instead, the study has to focus on those basic functions of the government, necessary to prevent the total disintegration of the state, which is thought to be capable eliminate the spread of the terrorism. When examining the efficiency requirements of the state in their relation with the terrorism, it should be emphasized the specialties that reflect the failures of the states in North Africa.

Many political analyzers believe that the Arab Spring has led to the "arc of instability" in North Africa, which gave a path to the Al-Qaeda and its affiliates to have a safe haven here, and implement terrorist attacks from this basis ${ }^{1}$. The arc of instability covers Somalia, Ethiopia, Sudan, Chad, Niger, Nigeria, Libya, Tunisia, Algeria, Morocco, Mauritania, Mali, and Egypt. The AQIM (Al-Qaeda in the Islamic Maghreb) and its affiliates, however, have been in Chad, Niger, North Nigeria, Mali, East Mauritania, Western Sahara, South Tunisia, and South Libya, which are not coincided either with the countries of Arab Spring, or with the collapsed and failed states. Somalia and Sudan have nothing to do with the Arab Spring, but Al-Qaeda affiliates have infiltrated in these countries, too. Consequently, it should be other factors as well that determine the increasing terrorism here.

\section{Means of Measuring the Terrorism and the Quality of the State}

Africa is a continent of superlatives:

(1) The poorest continent: $50 \%$ of the Africans live less than $\$ 1$ per day;

(2) The fastest population growth: 3.5\% per year can be seen in the urban areas;

(3) The highest proportion of people having AIDS (Acquired Immune Deficiency Syndrome) is found here;

(4) Africa has the highest proportion: $66 \%$ of people living on agriculture;

(5) Here is the highest proportion: $75 \%$ of people under the age of 25;

(6) The lowest proportion: $6 \%$ of the cultivated lands are in Africa.

It should be mentioned that the aforementioned superlatives are true to the whole continent, but there are sufficient differences between the countries in the regions of Maghreb and Sahel in North Africa. Egypt, Libya, Algeria, Tunisia, and Morocco in the Maghreb are highly more developed from many perspectives, such as economy, political culture, state system, infrastructure, human services, etc., than Mauritania, Mali, Niger, Chad, Sudan, Nigeria, Somalia, and Ethiopia in the Sahel.

The question the study tries to answer is that the countries in North Africa in what sense should be considered as efficient or inefficient states, and if any conclusion can be drawn between these factors and the increasing danger of the terrorism that developed during the last decade since 9/11 in this region.

The map on the most wretched places (see Figure 1) shows the safe havens of the terrorists that have been founded among others, in the Sahel, however, there is no any failed state, only one critically weak state Chad here. A map made by the ACLED (Armed Conflict Location and Event Dataset) on the Conflict Actors in North Africa and the Sahel Region (see Figure 2) in 2012 shows that the most active Al-Qaida affiliates and allies can be found in Northern Mali, but many in the northern part of Mauritania, Niger, Chad, and the southern part of Algeria and Libya, as well. These countries belong to the Sahel in North Africa.

\footnotetext{
1 Alexander, Yonah. (2014). Terrorism in North Africa and the Sahel in 2012: Global reach and implications (p. 4). Inter-University Center for Terrorism Studies, Potomac Institute for Policy Studies, Arlington, VA 22203, February, 2014.
} 


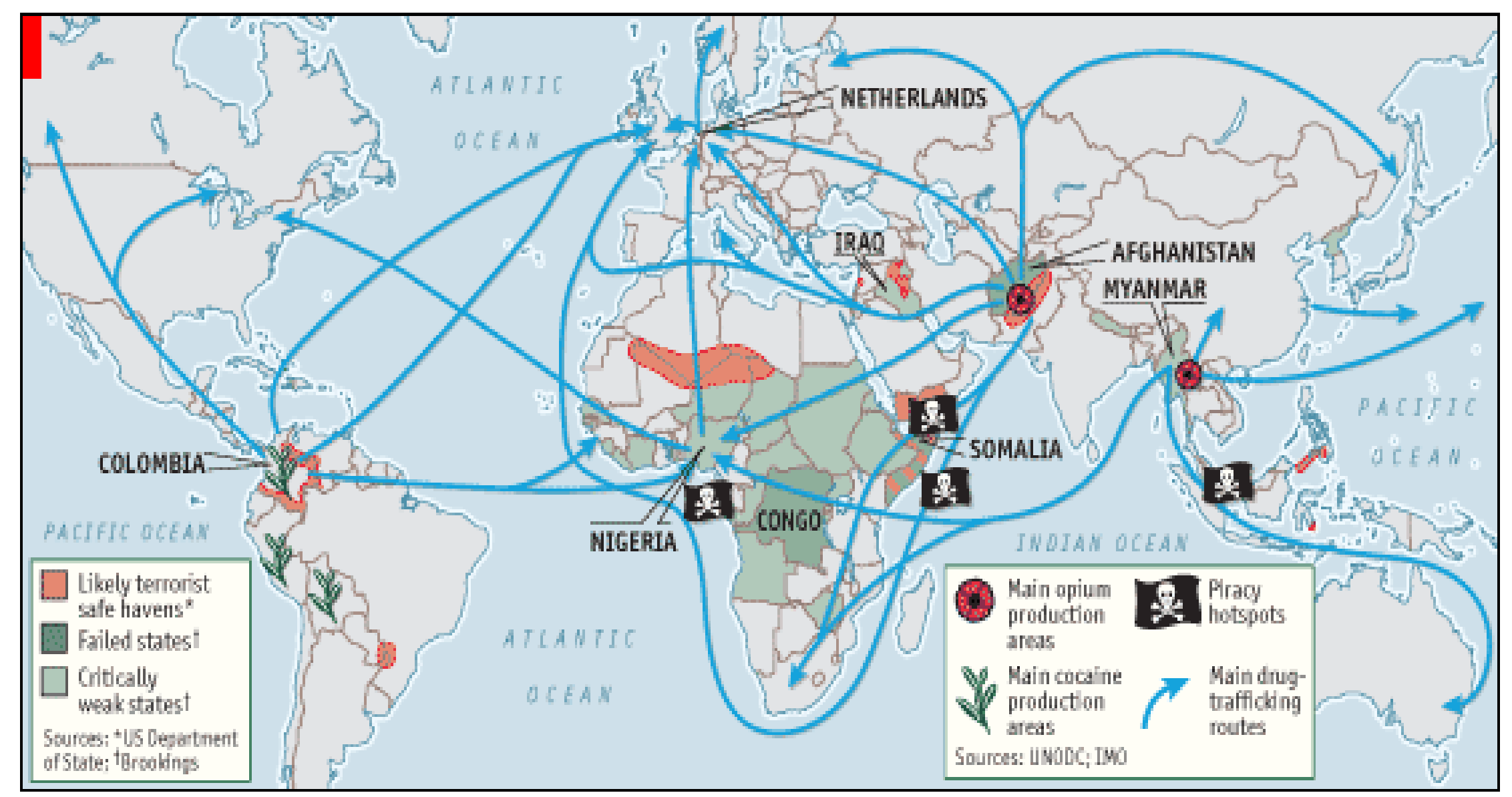

Figure 1. Map on global drug trafficking, piracy, and terrorist safe havens ${ }^{2}$.

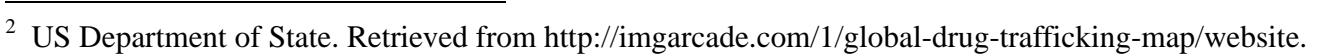




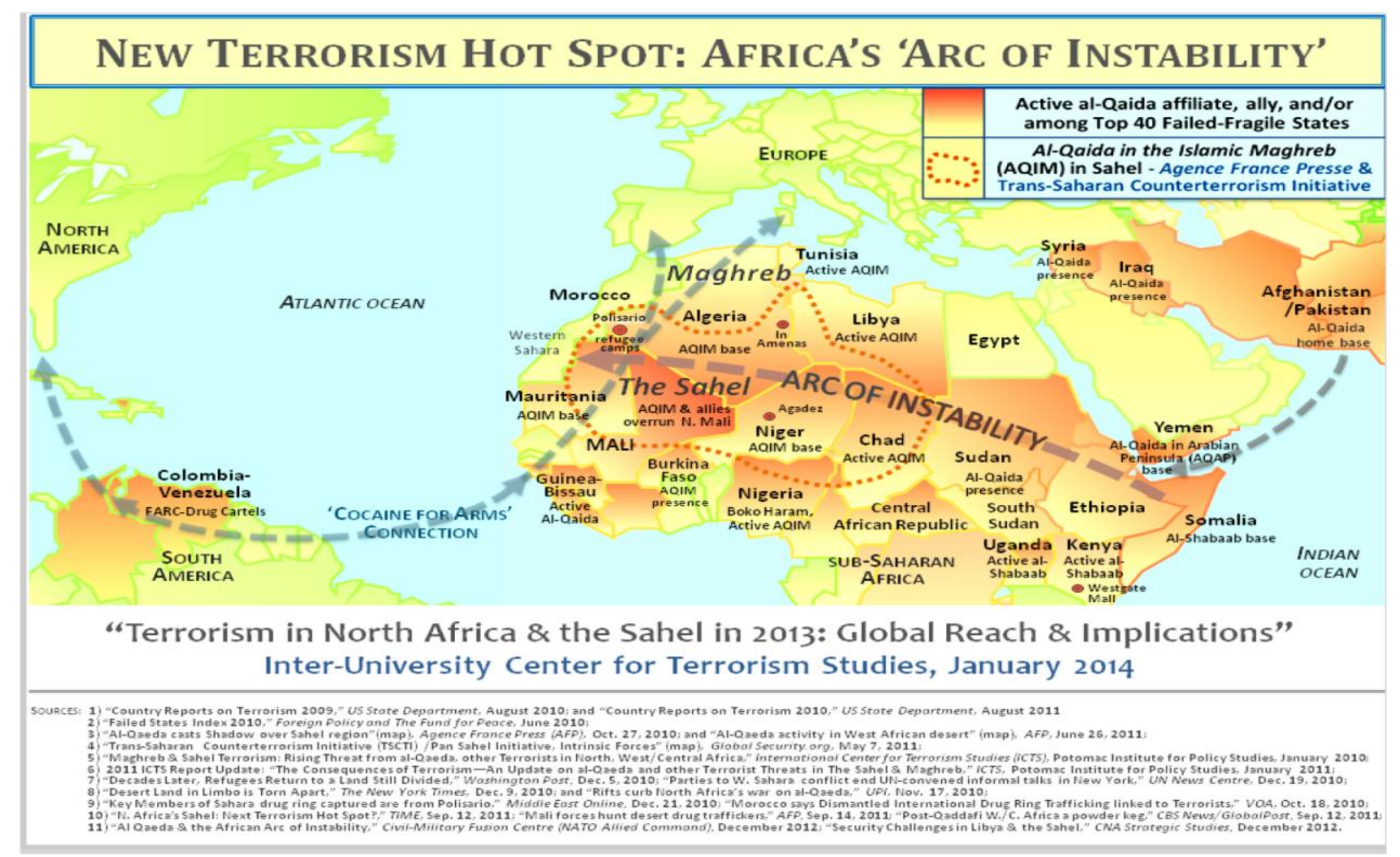

Figure 2. New terrorism hot spot: Africa's arc of instability ${ }^{3}$.

\footnotetext{
${ }^{3}$ Inter-University Center for Terrorism Studies. Terrorism in North Africa and the Sahel in 2013: Global reach and implications.
} 
The diagram made by the ICTS (Inter-University Center for Terrorism Studies) about the "Terrorist attacks in the Maghreb and Sahel since 9/11" shows that the number of the terrorist attacks increased from 21 to 204, almost 10 times more, by 2009, and decreased by 144 in 2012 (see Figure 3). The number of the terrorist attacks since 9/11 was extremely high in Algeria—1,285, between 27 and 58 in Mauritania, Mali, Niger, Chad, and Ethiopia but relatively low, between four and nine in Morocco, Tunisia, and Libya.

The “Terrorism Risk Index of 2013” (see Figure 4) shows that the extreme high risk of the terrorism can be identified in Algeria, Sudan, Nigeria, and Somalia among the North African countries, which does not exactly mean the area of Sahel.

The aforementioned data show that the safe havens of the terrorists are the area, where the terrorism has a high risk, but on the other hand, it is diverging, too. The safe havens are the place for the basis of the terrorist groups, where the terrorists can hide, recruit, and train terrorists in the terrorist camps. The extremely high risk of the terrorist attacks means, however, that the most terrorist attacks have occurred, or will most probably occur in the given area.

The "Index of the Political Violence and Terrorism Risk" (see Figure 5) shows that most of the North African countries belong to the severe category. Algeria, Mauritania, and Ethiopia are in high risk, and only Morocco has a medium risk. It can be seen from these indexes that the risk of the political violence and the terrorism is much higher in North Africa than the risk of the terrorism itself, which calls the attention to the fact that this region is especially threatened by insurgences, civil wars, riots, rebellions, uprisings, and human rights violations, such as mutilation, stoning to death, lashing, torture, and execution ${ }^{4}$.

It should be noted that the risk of the political violence and terrorism is also severe in other countries in Middle Africa and the Middle East. The reason for the high risk of the terrorism in the Middle African countries, such as the Central African Republic, the Democratic Republic of Congo, Uganda, and Rwanda, is the operation of a non-Islamic terrorist group, the Lords' Resistance Army here. The political violence has been high, too, because of the local tribal conflicts.

The next step of the study is to identify the methods for the measuring of the inefficient versus successful states, and set up a preconception, if it is related to the features of the terrorism in North Africa.

According to the "Failed States Index of 2013" (see Figure 6) made by FFP (Fund for Peace) countries, such as Sudan and Somalia in North Africa or Congo in South Africa are identified as the three failed states in the alert category in all over the world. Ethiopia, Chad, and Nigeria are in the second worth, in the warning category; Egypt, Libya, Algeria, Morocco, Mauritania, Mali, and Niger are in a better category, but do not belong to the stable and sustainable countries, either. Stable and sustainable states can be found just in Western and Eastern Europe, North America, Australia, and New Zealand.

The widest accepted criteria of the failed state are as follows:

(1) Human dimension:

(a) Demographic pressure;

(b) Massive movement of refuges;

(c) Chronic sustained of human flights;

(d) Violation of human rights.

\footnotetext{
${ }^{4}$ J. F. Forest-Giroux, Jennifer. (2011). Terrorism and political violence in Africa: Conpemporary trend and a shifing terrain. Journal of Perspectives on Terrorism, pp. 1-7.
} 
(2) Political/Government dimension:

(a) Group grievances;

(b) Lack of legitimacy of government;

(c) Week security apparatus (military and police);

(d) Rise of factionalizes elite.

(3) Economic dimension:

(a) Economic recession;

(b) Poverty-economic inequality;

(c) Declining level gross domestic product (GDP)/capita;

(d) Corruption.

(4) Public service dimension:

(a) Inefficient infrastructure;

(b) Epidemics;

(c) Poor health and education;

(d) Inefficient food and water supply.

Besides the Failed States Index, there are three other indexes, such as corruption (see Figure 7), global peace (see Figure 8), and democracy (see Figure 9). These indexes show almost the same: The stable and sustainable states are the best ones from the point of view of corruption, peace, and democracy, but North African countries have the lowest level of peace, the highest corruption, and the lack of democracy is typical. The "democracy index" has six segments: electoral process, pluralism, civil liberties, functioning of government, political participation, and political culture. North African countries are authoritarian (Chad, Somalia), flawed democracies (Libya, Mali, Tunisia), or hybrid (Morocco, Mauritania, Egypt, Niger), and the rest ones (Algeria, Nigeria, Ethiopia) are still fairly problematic ${ }^{5}$.

We can draw the conclusion on the basis of the aforementioned indexes that terrorism is not closely connected with the failed characteristic of the states ${ }^{6}$. The question to be answer is, what kind of factors have led to the contemporary situation, i.e., North Africa has been increasingly jeopardized by the terrorism?

\footnotetext{
${ }^{5}$ Kennedy Boudali, Lianne. (2007). The Trans-Sahara counterterrorism partnership (p. 8). The Combating Terrorism Center, United States Military Academy West Point.

${ }^{6}$ Colonel A. Dempsey, Thomas. (2006). Counterterrorism in African failed states: Challenges and potential solutions (pp. 1-4).
} 


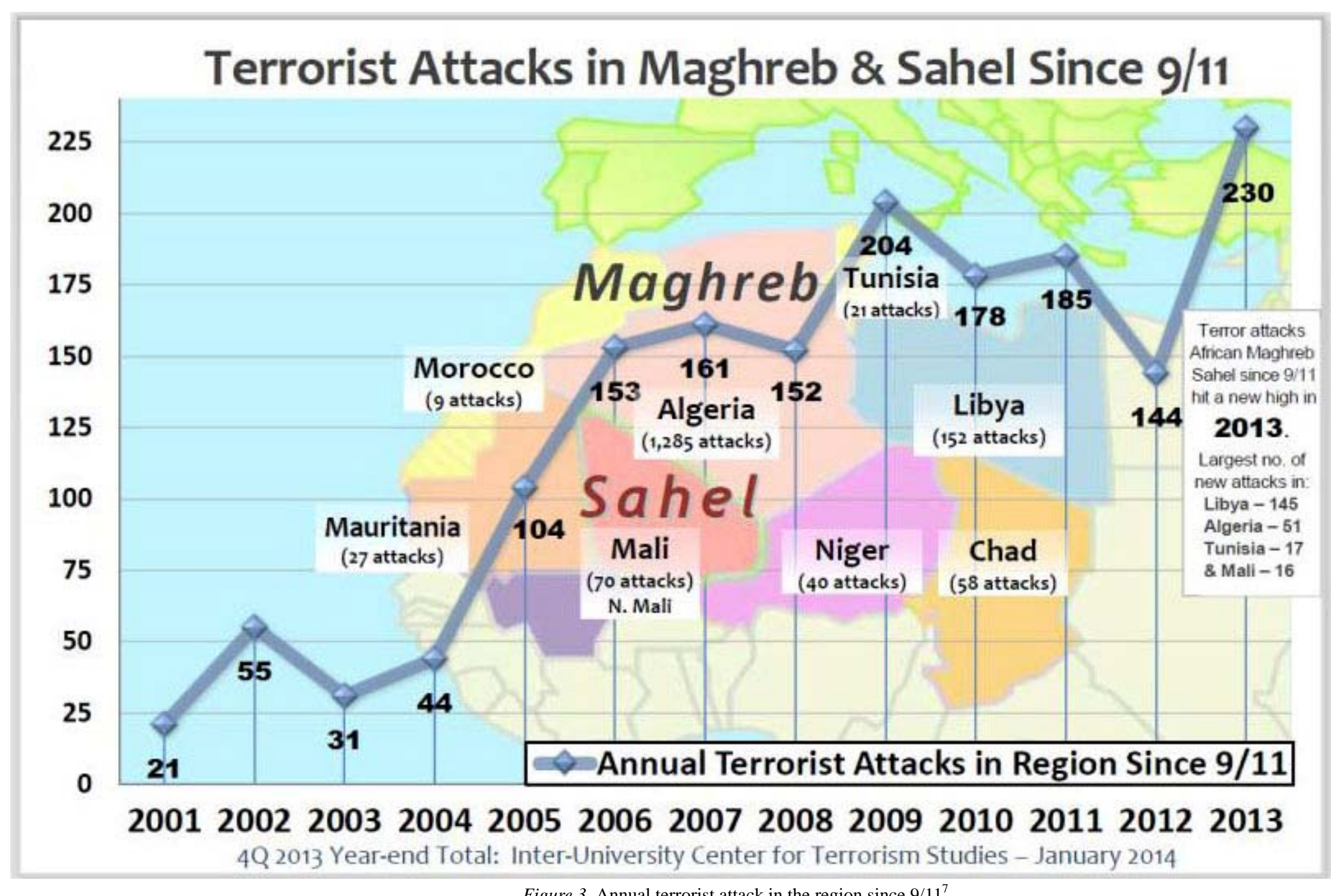

Figure 3. Annual terrorist attack in the region since 9/11 ${ }^{7}$.

${ }^{7}$ Inter-University Center for Terrorism Studies. Terrorism in North Africa and the Sahel in 2013: Global reach and implications. 


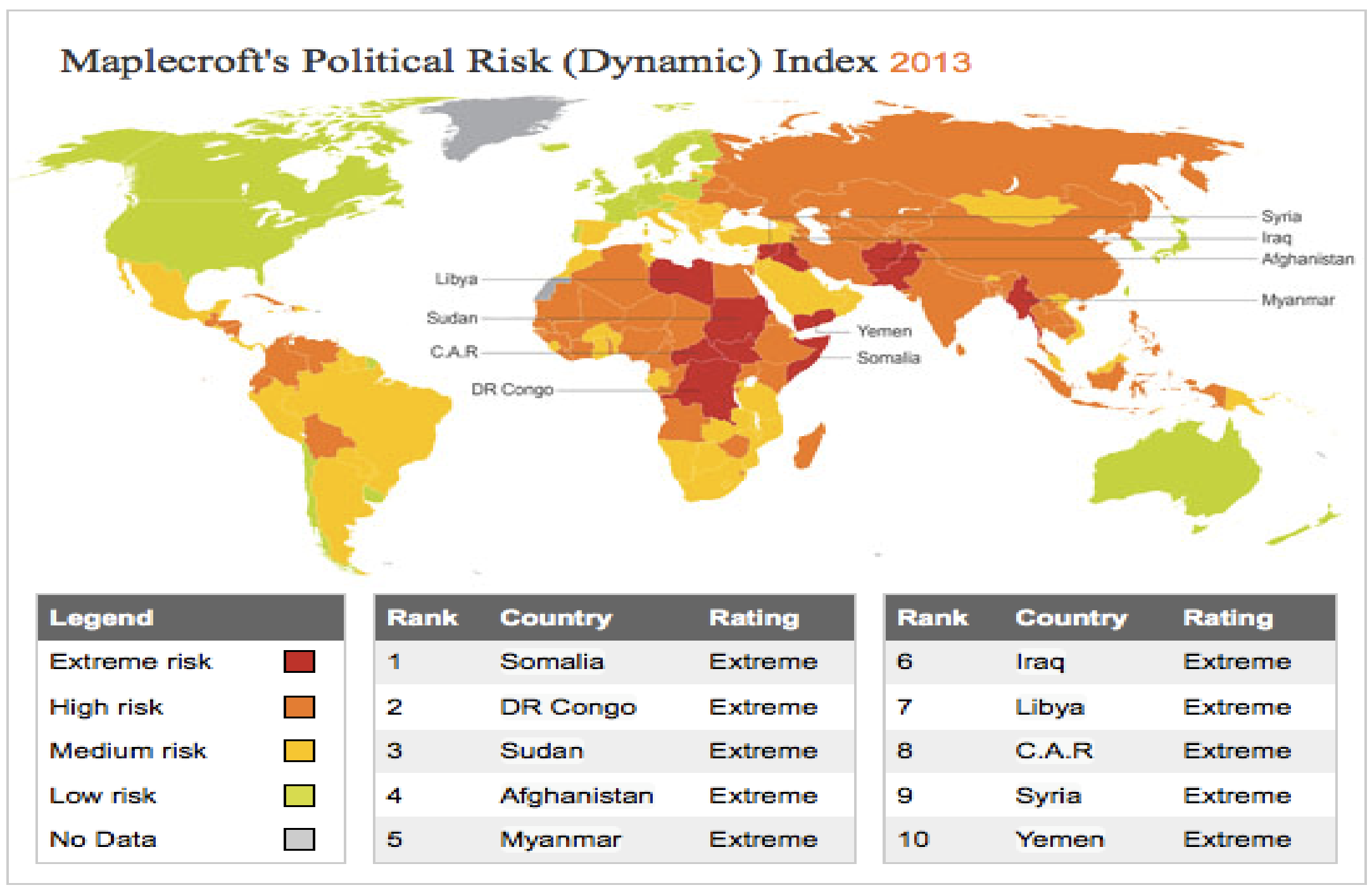

. Maplecroft, 2013

Figure 4. Terrorism risk index of $2013^{8}$.

${ }^{8}$ Maplecroft. Political Risk Atlas, Terrorism Risk Index 2013. Retrieved from http://www.bbgstrategy.com/2013/01/maplecroft-releases-2013-political-risk-atlas/. 


\section{Terrorism \& Political Violence Map}

\section{AON}

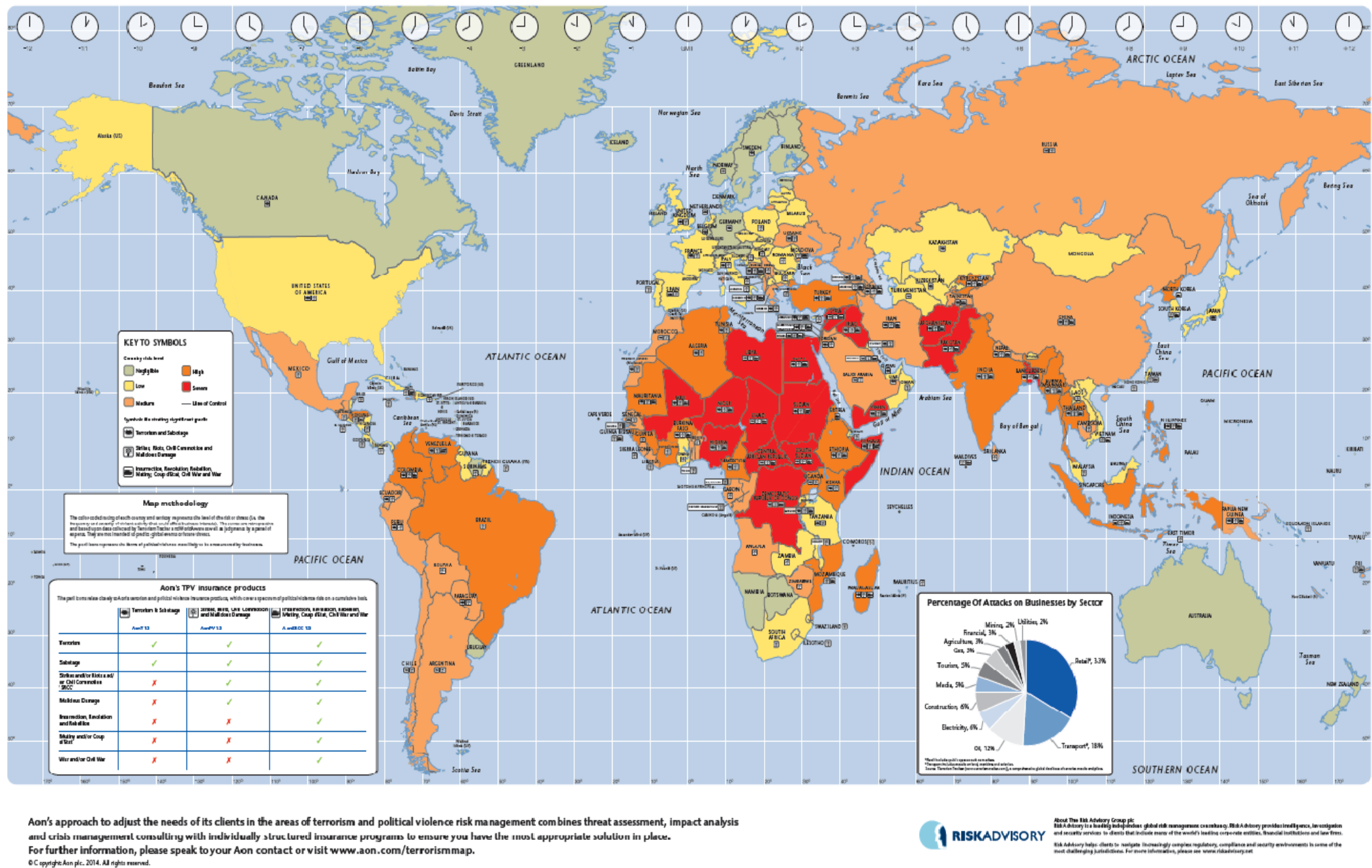

Figure 5. Terrorism and political violence $2014^{9}$.

${ }^{9}$ Aon. Terrorism and political violence map 2014. Retrieved from http://www.phibetaiota.net/wp-content/uploads/2014/04/. 


\section{FFFP FragileStatesIndex 2014}

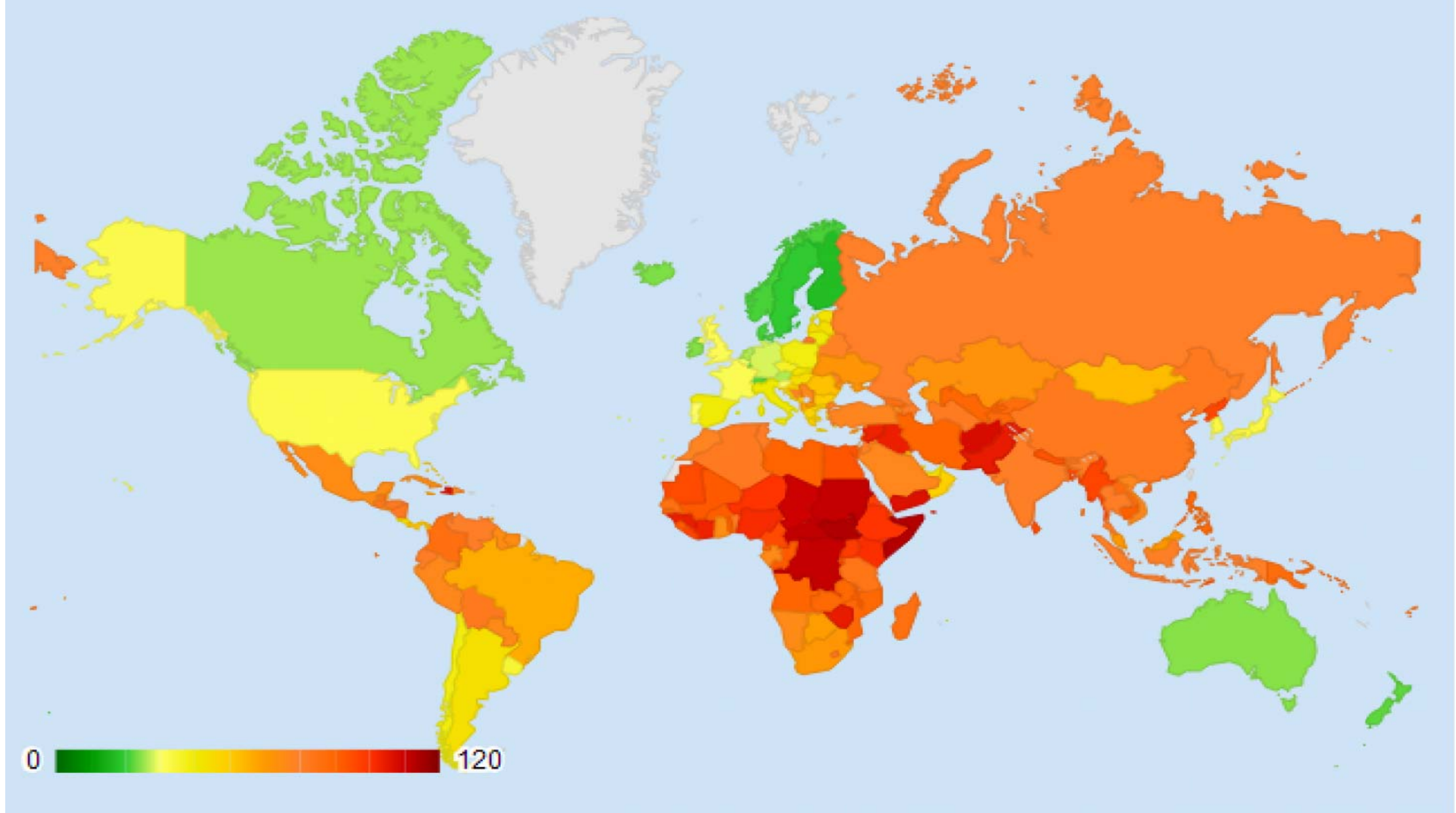

Figure 6. Fragile States Index $2014^{10}$

\footnotetext{
10 Found for peace: Fragile State Index 2014. Retrieved from http://www.washingtonpost.com/blogs/monkey-cage/wp/2014/07/14/is-ranking-failed-or-fragilestates-a-futile-business/.
} 


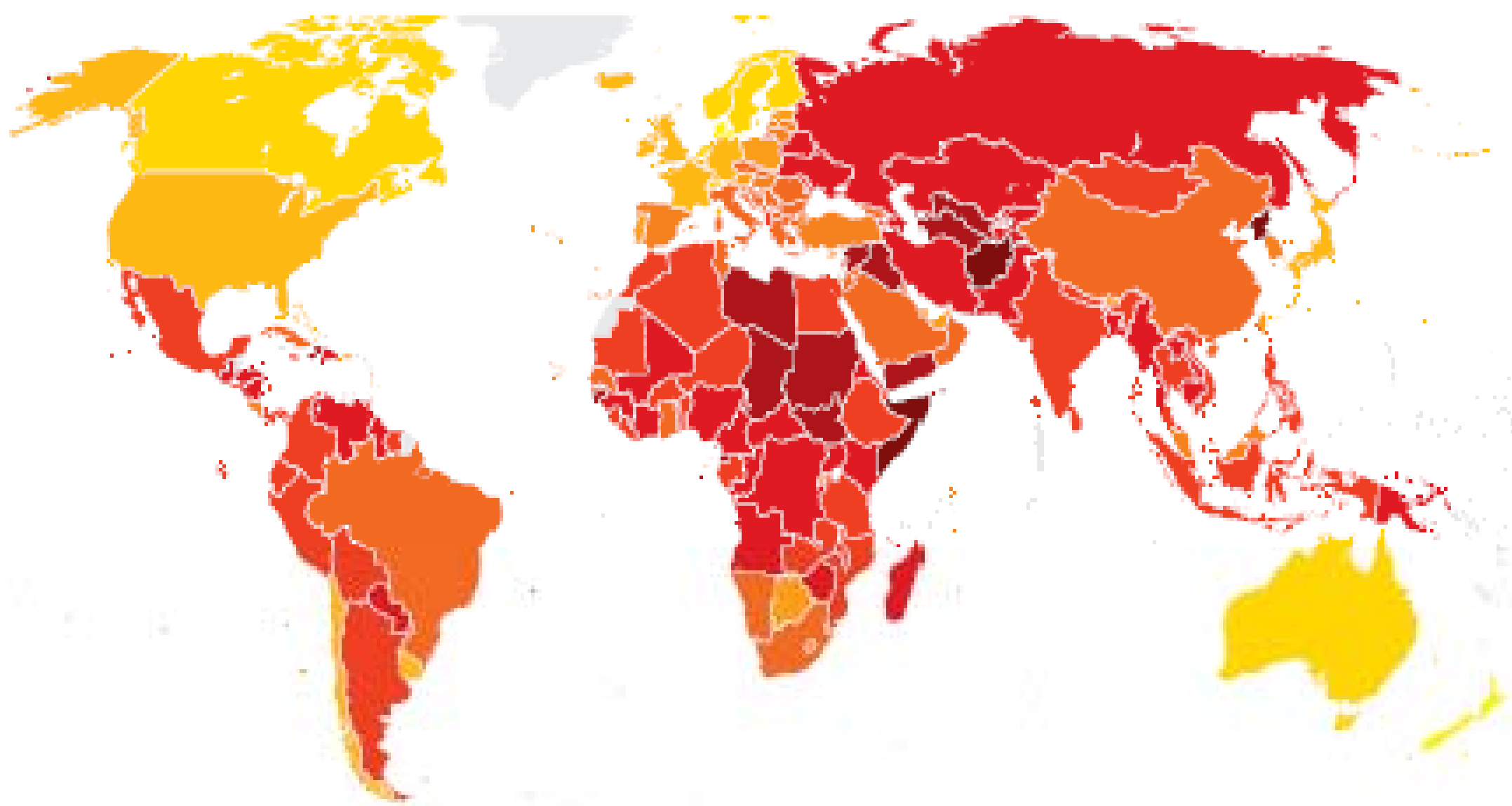

Figure 7. Corruption Perceptions Index $2013^{11}$

11 Transparency International. Corruption Perception Index 2013. Retrieved from http://transparency.hu/uploads/docs/cpi_info_2013.pdf. 


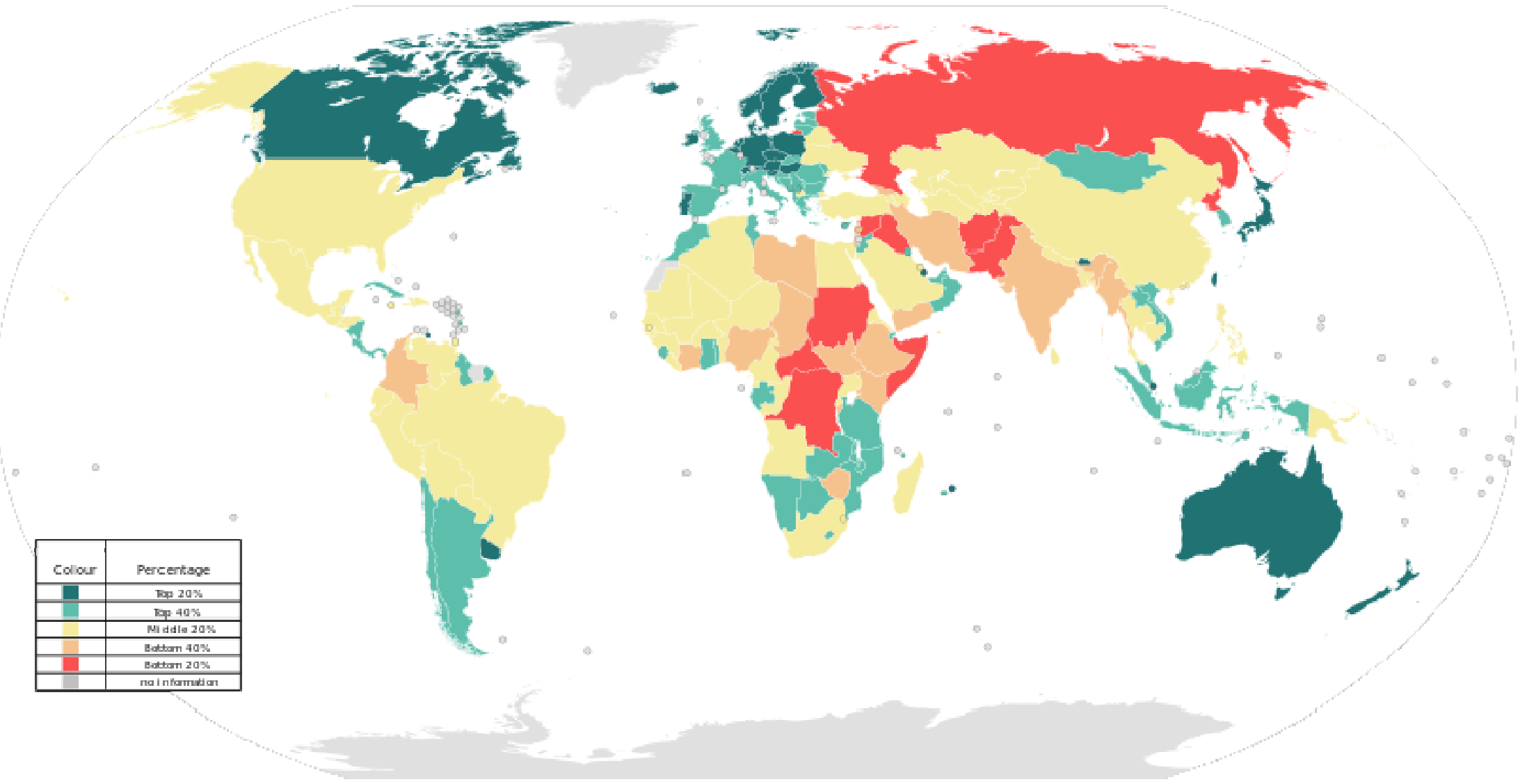

Figure 8. Global Peace Index $2014^{12}$.

${ }^{12}$ Institute for Economic and Peace. Global Peace Index 2014. Retrieved from http://mashable.com/2014/06/19/u-s-peaceful-countries/. 


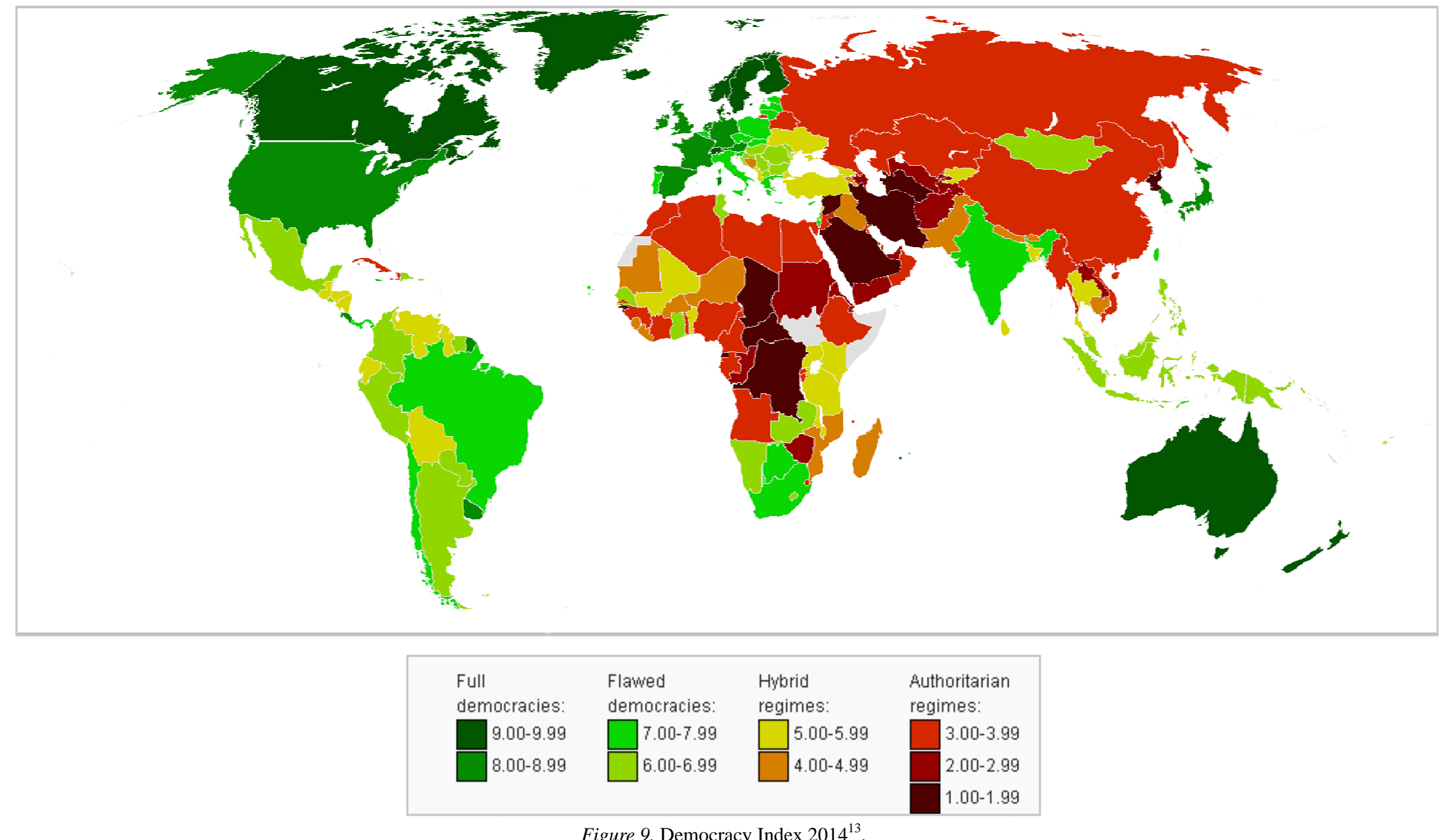

${ }^{13}$ Economist Intelligence Unit Democracy Index map for 2014. Retrieved from http://en.wikipedia.org/wiki/Democracy_Index. 


\section{Requirements of State Efficiency in North Africa}

On the basis of the aforementioned analyses, conclusion can be drawn that the indexes mapping the failures of the states do not give a clear pictures about the reasons of the increasing terrorism in North Africa. Instead of these indexes, the study will examine this problem form another aspect: the special questions of state efficiency in North African countries.

The study has outlined the following segments of the efficient state that will be examined as determining factors of the terrorism, and also, the means of combating against terrorism in North Africa.

(1) Stable and predictable government:

(a) Permanent lack of legitimacy is typical, because autocratic presidential systems and military juntas are changing all the time. Neither of them have legitimacy due to their democratic deficit;

(b) The scenario: coup-d'etat—military junta—legitimating afterwards by parliamentary and presidential elections, new constitution confirmed by referendum. The elections and the referendum are often not fair;

(c) A government shall be considered as legitimate if it is based on free and democratic elections, multi-party system, check and balances in the state system, and the constitution is accepted by the majority of the population.

(2) Strong central and local government:

(a) Strong but not brutal military forces and police, effective intelligence, coherent jurisdiction in order to cope with the armed conflicts and terrorist attacks;

(b) Protection of human rights by the legislation and jurisdiction. Autocratic states in North Africa are typical in this region, which is the hotbed of riots, revolutions, and uprisings;

(c) Control of the territory and borders by the law enforcement, because there are nomadic tribes and desert areas in North African countries, what is a safe haven for the terrorist groups.

(3) Implementation of public tasks:

(a) Public goals can be determined only by a pluralist system, where besides the public authorities, political parties, NGOs (non-governmental organizations), trade unions, lobbies, and other organizations of the civil society will participate in the decision-making process. Instead of these requirements, it is typical in North Africa that a small minority of the population owns the political power;

(b) Special public tasks emerge in the North African countries, such as economic development, management of demographic pressure, epidemics, desertification and water scarcity, infrastructure development, social welfare services (health care, education, employment programs), fair redistribution (proportional taxation, increasing living standard), etc.

(4) Transparency and accountability:

(a) Corruption is especially high in the North African countries. This is why transparency and accountability has a special importance here;

(b) Integrity means that the operation of the public authorities shall be based on the rule of law and ethic codes;

(c) Open society requires access to public data, free media, freedom of speech, freedom of assembly, and freedom of association;

(d) Mechanism against corruption should have independent controlling authorities, unbiased jurisdiction, and institutions for the prevention of corruption. 
(5) Prevention and management of internal conflicts:

(a) Several internal conflicts caused by ethnic, religious, social, political, etc., hostility can be seen in North Africa;

(b) In case of internal armed conflict, a compromise will be needed with the opposition, instead of brutal reprisal;

(c) In order to solve the internal conflicts, well fit mechanism of mediation and reconciliation should be applied;

(d) Motivated, well-trained, and equipped law enforcement, also, military forces used modern procedures are needed against terrorist groups;

(e) Indexes of failed state, democracy, global peace, corruption, and the requirements of state efficiency have overlapping in their points of view, but it should be underlined that the latter one is more complex, so, has been better adjusted to the specialties of North African countries.

\section{The Stable and Predictable State vs. Terrorism}

\section{The Colonial Heritage in North Africa}

The aim of the colonial states was to extract resources for their benefit. Colonial states, which were authoritarian, weak, corrupt, and did not have legitimacy, had just little concern for the improvement of the population's conditions. Only the industrial infrastructure was developed, but not other public services, such as health, education, housing, energy and water supply, public transportation, or the public goals, such as economic development or employment.

After the colonial states had become independent from their colonists since the 1950s in Africa, a special political system developed in the most part of the continent that inherited the structure and political culture of the colonial states. These new independent states were typified by the rising of the new, small, local elite, which was westernized, but followed their private goals, not the public interest. The independence wars were fought primarily by this small group of educated Africans, but there was no middle class that could have held a control over the new elite. The majority was suppressed by the small privileged elite. The serious inequality in these societies remained unchanged and unjust, corrupt and unaccountable governments developed in the continent.

As a result, the majority, approximately $85 \%$ of the population lived in rural areas, and worked in the agriculture. They are the losers of the independence wars. Rural areas were not developed, because the state resources were distributed to the elite. The farmers have to pay extremely high tax, which is in Tanzania, e.g., $84 \%$ of the population of the rural areas remained poor, with extremely low income, without basic human services, such as education, health care, social aids, labor opportunities, or infrastructural public services, such as water and electric supply, canalization, public transport, roads, etc. This population did not have any chance to express their interest in the authoritarian state system.

The states have an exclusive right to extract the natural resources, so the public administration and the business matters have been interwoven and controlled by the local elite. The political elite, in order to keep their political power, centralized the public administration, prohibited the multi-party system, eliminated checks and balances in the state system, and implemented an extreme spoil system, in which the patronage became the rule. This structure has become the hotbed of corruption at state level. Nigeria can be mentioned as the most extreme example to the phenomena: The country is rich in oil, but the huge income from the oil production has 
not even appeared in the state budget, because it will directly be transformed to the private bank accounts in foreign banks ${ }^{14}$.

The political system was based on a one-party system, and the autocratic state lacked democratic values, instead, centralization, patronage system, and corruption prevailed. These states in most cases, however, were not strong dictatorships, e.g., Libya, but weak and unstable. This is why coup-d'etat could happen so frequently by the military forces and establish military juntas, or in better cases, autocratic presidential systems.

\section{Autocratic Governance in the North African Countries and the Questions of the Stability of the State}

Autocratic presidential system. The presidential system in North Africa does not mean a Western-type democratic model, but an autocratic one. It is typical in these countries that the autocratic governments can keep their power for decades, or, are often changed, but in both cases come to power by coup-d'etat, not parliamentary elections.

When parliamentary elections or referendum are held, they are in most cases not fair and free, but serve to confirm the president or the constitution, in order to give them legitimacy, after the president has not been democratically elected, or the constitution has not been based on a wide recognition of the population. A military leader in most cases acquires the political power by coup-d'etat, and become the president.

It also often happens that the president tries to keep his position, and makes the parliament amend the constitution to regulate that the president can be elected unlimited times.

The president in these autocratic systems tries to centralize the political and the state power in his hand, which means that there are no political parties, or just one in the parliament and it is the right of the president to appoint the prime minister and his cabinet, the president of the Constitutional Court and the Supreme Court.

There is no way in such a system for the social groups to express and enforce their interest, in other words, this practice is against a democratic value, the pluralism. Checks and balances, which is another democratic principle, i.e., the power sharing in the state system, does not work, either: The branches of power, such as the legislation, jurisdiction, constitutional supervision, and public administration have served only as a decoration, but did not have a real competence.

Examples to the autocratic presidential system in North Africa. In Egypt, after the monarchy had been overthrown in 1952, the Nasser, the Sadat, and the Mubarak governments representing a strong and stable presidential system, implemented some reforms in the field of land, education, social mobility, liberalization, economic development, etc., however, violated the human rights and introduced the Sharia law.

Algeria also had a strong and stable political and state system based on autocratic features. After the FLN (Front de Libération Nationale-National Liberation Front) had won the independence war against France in 1962, the first two governments strengthened the military forces and nationalized the oil industry. Only the Bendjedid government liberalized the economy and implemented economic reforms since 1970. A social unrest that unfolded against the autocratic system in 1980 demanded a multi-party system. As a result of the former state policy that emphasized the Arab culture in the society and public life, the FIS (Front Islamique du Salut-Islamic Salvation Front) won the election in 1991 and established a broad coalition of Islamist groups. The government cancelled the result of this election and banned the FIS. A civil war between the FLN and FIS

\footnotetext{
${ }^{14}$ Pecoraro, Alberto. What are the political causes of failed states in Sub-Saharan Africa, July 31, 2012. University of York, Publications, Politics and Development, E-International Relations. Retrieved from http://www.e-ir.info/2012/07/31/what-are-thepolitical-causes-of-failed-states-in-sub-saharan-africa/.
} 
broke out, and ended only by 1999. Free election was held, and president Bauteflika could reach the political stability by giving amnesty to the FIS. The Bauteflika government had to face the strengthening of the GSPC (Salafist Group for Call/Preaching and Combat) which followed an aggressive, extreme, fundamentalist policy against the government, but the government tried to reconcile the national hostilities. Despite the political, economic, public sector and social reforms, such privatization, liberalization, successful employment and housing policy which tried to modernize the country, the state remained an autocratic one-party system: The president was the head of the army, and the most important public authorities, and had the right to appoint the prime minister.

Tunisia won the independence from France in 1956. Ben Ali acquired the power in 1987 by coup-d'etat from the Bourguiba government and ruled in an autocratic presidential system until 2011. This regime was corrupt, violated the human rights and could not solve serious economic and social problems, such as unemployment and inflation.

The history of Mauritania saw a lot of coup-d'etat since 1964, when the state became independent, but still based on one-party system and authoritarian presidential regime. President Daddah was reelected more times until 1976, when a military junta acquired the political power and kept it until 1980. Taya was elected as the president in 1980 first, but reelected in 1992, 1997, and 2003. In 1987, the Black from Senegal attempted a coup-d'etat, but it was not successful. In 2005, another military coup established a Military Council that implemented election and referendum. Abdallahi was elected as president at that time, but finally in 2008, Abdel Aziz General acquired the political power by military coup, and was elected as president. Multi-party system was introduced only in 1991.

In Mali, the Keita regime came to power in 1960, when the country became independent. A military coup led by Troare in 1968 acquired the power until 1991, when another coup-d'etat represented by the opposition of Troare tried to overthrow the Troare regime. It was not successful, and Troare brutally suppressed the opposition, arrested and tortured its members. A civil war broke out with harsh fight in the country between the government army and the opposition parties and civil groups. The military finally put down the arms, then, Troare was arrested and sentenced to death. The new president Touré was elected in 1997, and could establish stability and good relation with France and the US.

Niger is also a typical country, where the coup-d'etat frequently changed each other during its history since its independency of 1960. In 1967, a civil war between the North and the South caused by ethnic, tribal, and religious hostility broke out, and resulted many killed people, disease, and starvation. The multi-party system was introduced more times, but coup-d'etats did not finish: Failed military putsch, assassination, and rebellions have been typical until this time.

Nigeria cannot be considered as a stable state, either. Its history since its independence from the United Kingdom in 1963, has been full of military putsch, rule of several military juntas, civil war, unfair and unfree elections, ethnic violence, brutal reprisals by rapes, tortures, cruel treatments, detentions, executions, etc., violence of human rights, such as human traffic, prostitution, forced labor, child labor, discrimination of regions, sex, and ethnic. State corruption is extremely high, and also the immigration of the population to the US.

Chad became independent form France in 1960. Its history saw two coup-d'etat, in 1987 and 1990, two civil wars in 1965 and 2003, but two rebellions in 2006 and 2009. President Deby who acquired the political power by military putsch in 1990, was reelected many times, and at the moment is still the president of Chad in a one-party system. The country has serious economic and social problems as well, such as state corruption, 
poverty, and violence of human rights.

Sudan has a worst history in North Africa. Since its independence from Egypt and the United Kingdom in 1956, altogether 11 presidents came to power, half of them by military putsch, the other half by non-free and unfair elections. There are no political parties until this time. As a result of a harsh civil war with genocide and many refugees in 2003 in Darfur, between the government and the non-Arabic, black population, the South Sudan became independent by the referendum in 2011, but there are still serious armed conflicts in this area. The country has one of the most important oil productions in Africa, but more than half of the population lives in rural areas, and work in the agriculture.

Ethiopia was an empire from 1945 to 1974, then a communist state, and only became a republic based on multi-party system since 1990. The state system is considered autocratic, and political liberty rights are not guaranteed. The country can be considered as a stable state, with a strong army, however, extremely poor, without natural resources. The population lives on dominantly from the agriculture.

Somalia became independent in 1960 from the United Kingdom, when a presidential system was established, free election was held, and a constitution was accepted. The president was assassinated this year, and Siad Barre acquired the political power by military putsch. The Siad Barre socialist government that ruled until 1991, was under the influence of the former Soviet Union, nationalized the private properties and implemented successful economic and social programs. Until the hostilities in 1990 between the landlords and the Islamic fundamentalists, it was a stable state, but due to the two civil wars, the state collapsed. This was among others, because the Soviet control was finished by the beginning of the 1990s. The temporary government, the TFG (Transitional Federal Government) came to power, but could not dominate in powering the country, even in the capital. The country has been directed by a tribal assembly, too, until this time. The ICU (Islamic Court Union) represented by Islamic extremists, occupied almost the whole counties, but still survived in the form of a terrorist group, the Al-Shabaab. In 2010, the country became a federal republic, with a new constitution, but still has to face with an anarchy in the country.

Constitutional monarchy. The only constitutional monarchy in North Africa is Morocco, but it is not a Western type, either. The most important difference is that the king has a wide competence over the state system, while the kings in Europe play a balancing role based on their prestige and represent the unity of their nations without real authority.

After King Mohammed VI had died in 1999, his son, Hassan II came to the throne. The king's competence in Morocco:

(1) Supervises the executive power and appoints the prime minister and his cabinet;

(2) Can override the decisions of the government and dissolve the parliament, as well;

(3) Can issue decrees, which have the force of law.

The legislative power has been divided between the government and the parliament, however, as mentioned above, the king has a wide competence to control both the government and the parliament. The multi-party system was introduced and political reform was implemented in 1999 by Hassan II, who is as opposed to his father, who tried to suppress the parliament and did not hinder human rights abuses—considered as a reformer.

Military juntas. As mentioned before, the political power of the military junta is not rear phenomena in the continent of Africa. The North African states that the author described above as presidential systems, used to be military juntas in many times, but typically just in a relative short time. As mentioned, the military leaders 
who implemented the coup-d'etat, tried to legitimate their political power and became president. It is another question that it in most cases does not happened in a democratic way, and the presidential system they established were in fact autocracy, which differs from the military junta only with the formal existence of the branches of the state power.

The most extreme example to the military junta in North Africa is Libya under the power of Gaddafi, who, after he acquired the political power by overthrowing the monarchy in 1969 by coup-d'etat, established the so called "Great Socialist People’s Libyan Arab Jamahiriya” which is naturally not a new type of the government, but named by Gaddafi. In fact, it was a dictatorship in the form of military junta. Kaddafi often called himself as "the king of the kings in Africa".

Gaddafi had an unlimited political power represented an extreme dictatorship until the revolution in 2011. The $80 \%$ of GDP was based on the income from the oil production. This wealth of the country gave him an opportunity to develop social security, housing, and education. After the UN (United Nations) sanction in 2003, Gaddafi was forced to implement some reform, such as liberalizing the economy, privatizing 100 state-owned enterprises, reducing state subsidies, pursuing a less aggressive foreign policy, etc.

\section{Conclusion on the Autocratic-Type Governance and the Problem of State Instability}

On the basis of the analyses above, the study can make the conclusion that there is sufficient difference between the countries in Maghreb and Sahel from the point of view of state stability.

Countries in Maghreb, such as Egypt, Libya, Tunisia, Algeria, and Morocco, had strong and stable autocratic governments, which were autocratic, but implemented some economic and social reforms, and could cope with serious internal conflicts, which only sometimes happened, e.g., in Algeria in 1999. Somalia and Ethiopia could be regarded as other examples outside the Maghreb, because they had a strong and stable government until 1990, when the influence of the Soviet Union finished.

Quite the contrary, the counties in the Sahel had many coup-d'etat, which undermined the stability of the state. These regimes, either in the form of military junta or presidential system, had just little success to implement economic and social reforms. They could not cope with the challenges of social and economic problems, the human rights violation, and the ethnic and religious conflicts, either. Corruption was extremely high in these countries.

The Arab Spring in 2011 led to undesirable effects in the countries of Maghreb.

In Egypt, the opposition that was not satisfied with the level of democracy, broke out a revolution in 2011. As a result of the revolution, an election was held. Morsi, who was supported by the Muslim Brotherhood that is considered as an Islamic fundamentalist terrorist group, won the election and appointed his cabinet from the members of Muslim Brotherhood. The traditionally strong military in Egypt could acquire the political power back from Morsi by coup-d'etat, and establish an interim government. Free election and referendum will decide about the new government and the constitution. Egypt will probably be capable stabilize its state system in the coming future.

A brutal civil war broke out in Libya in 2011, which required a NATO (North Atlantic Treaty Organization) military intervention based on UN mandate, too, and led to the total collapse of the Gaddafi regime. The reconstruction of the state system was not successful until this time: The National Transitional Council operates under political control and interim constitution, the General National Congress elected in 2012, has more political parties, one of them is affiliated with the Muslim Brotherhood. A referendum will be 
held later. The National Army of Gaddafi was defeated in the civil war, but could not been reestablished yet. So, militias control most of the areas of the countries, and the central government is fairly weak. Weapons of the Gaddafi government got in the hand of the terrorist groups of this region.

The Bouteflika government in Algeria survived the Arab Spring in 2010, because it could make a compromise with the opposition. As a result, the multi-party system was introduced, a free election was held, however, it was queried by many if it was fair, but as well as other political parties won seats in the parliament. Other political and constitutional reforms were implemented, too. There were economic and social problems, such as the dominant role of the state in the economy, high youth unemployment, housing shortages, etc., to which the Arab Spring called the attention. The Bouteflika government spent \$286 billion to human development, salaries, grants, and benefits in order to meet the demands of the opposite.

In Tunisia, the revolution initiated by the labor unions in 2011 led to a democratic process. Multi-party system was introduced, secular state and freedom of religious were enacted, equality as a constitutional right was accepted, and modern law was implemented instead of the Sharia law. The military had an apolitical role during these social changes.

The King, Mohamed VI in Morocco implemented political, economic, and social reforms due to the Arab Spring in 2011-2012. The power of the king was curbed, a new constitution was accepted by referendum, state-owned enterprises were privatized, and educational, social, health care reforms were performed. The king could keep his power in the way of compromise with the opposition.

The Arab Spring in the Maghreb that meant the unrest of the opposition of the autocratic governance here, was expressed in the form of riots, uprisings, revolutions, and civil war, and could change these anti-democratic state systems. The extent of the democratic processes has been different, however. The revolution in Libya could overthrow the Gaddafi regime, but left a chaos and disintegration in the governance, which can be explained by the least democratic tradition of the country in the region. The governments in Egypt, Algeria, and Morocco could keep the power when made a compromise with their oppositions. Tunisia, where the former government was so anti-democratic and inefficient that the compromise could not be made with the opposition, has been on the right track by a new democratic government in a democratic process.

The conclusion can be made that the success of the Arab Spring in the countries of Maghreb depended to a great extend on the level of democratic tradition and political culture. Not accidently, Libya, the former most extreme dictatorship in North Africa had the least success to establish a sufficient government after the collapse of the Gaddafi regime.

The countries in the Sahel were mostly avoided by the Arab Spring.

In Mauritania, the demonstration in the street in 2012 did not have any influence on the contemporary government.

Long before the Arab Spring, Mali had a revolution in 1991, which resulted free election and revolution and lunched democratic processes, such as the declaration of the freedom of religion, the secular state, and economic-social reforms, such as privatization and connection to the Western fiscal market by the help of the World Bank and the International Monetary Fund. Serious internal conflicts and social problems, however, remained in the country, which could not be solved by the weak government and the insufficient military.

Niger, Nigeria, Chad, and Ethiopia were not touched by democratic changes at the beginning of 2010s, however, Ethiopia is a much more stable country than the former ones. 
As mentioned, Sudan fell into the anarchy and the chaos after the rough civil war in Darfur since 2003. The collapsed state could not be stabilized even after the peace in 2005 and the referendum held in 2011 about the independence of South Sudan. The country is still in the place of dictatorship, serious armed conflicts, and a huge number of refugees. After Somalia, this is the third worst state in the Failed State Index.

Somalia became a republic and had a new constitution at the same time, in 2010, but is still a failed state on the top of the Failed State Index.

As it will be explained later, there is a close connection with the instability of the state and the terrorism, because the terrorist groups can find a safe haven in the collapsed states, such as Sudan and Somalia, where the state authorities are so insufficient, and law enforcement does not work to such an extent that they do not have to be afraid of being caught. Moreover, the terrorist groups can easily establish state authorities based on the Islamic fundamentalism, as well.

The stability can be assured only by legitimacy of the government, which supposes multi-party system, free, democratic, and fair elections, referendum and democratic governance, i.e., the real and effective checks and balances in the state system. Autocratic governments can be stable for a long time, but sooner or later will be overthrown either by coup-d'etat or the unrest of the democratic opposition. It is queried, if the stability will be able to be kept anymore when the autocratic state is collapsed.

\section{The Strong Central and Local Governments vs. Terrorism}

\section{The Ethnic and Religious Hostilities in North Africa}

The Islamic fundamentalism. The next issue the study will examine if the Islamic fundamentalism has been a tradition in North Africa, and if so, how it influences the terrorist tendencies in this region.

The Islam has basically there branches: the Sunni, the Shiah, and the Khawarij, which has many sub-branches, such as Shafi's Ima'ilism, Druze, Alawi, Akbari, etc. The group of Sufi forms a separate ideology and has seven sub-branches. The hostility between the Sunni and Shiah groups has been widely known as a part of the Arabic politics in the Middle East, like in Iraq, for example. There are also conflicts between the countries where the Sunni or the Shiah form the majority of the population, e.g., Iran, Saudi Arabia, Syria, Lebanon, Afghanistan, Iran, etc.

The liberal Islam admits that the Quran can be read in many ways, accepts the independent thoughts on it and tries to reconcile the religious. It is important that the liberal Islam emphasizes the secular state, and respects the human rights, e.g., the equality of the women.

The main characteristic of the fundamental Islam is that it returns to the fundamentals of the Quran ${ }^{15}$. It was originated in Egypt, during the 1940s, by the Muslim Brotherhood, and followed up in Iran in 1980, by Khomeini. The Hamas in Palestine was also founded in 1987 by the Muslim Brotherhood. The military leaders of the fundamentalist Islam could acquire the state power in Iran, Afghanistan, Algeria, Sudan, and Egypt during the last decades. The Islam fundamentalism could be rooted in those countries, where the population, e.g., the Talibans in Afghanistan, the Pastu in Pakistan, or the Shita Persians in Iran was responsive to it.

The fundamentalist Islam has basically to forms: Wahhabism and Salafism.

The Salafi Islam is a movement of the Sunni Islam, associated with the strict, literal, and puritan Islam, but

${ }^{15}$ Islamic fundamentalism. Wikipedia, the free encyclopedia. 
it has a minority group, the jihadists. The Salafi schools are originated from the second part of the 19th century as a reaction to the spread of the Western culture.

The Wahhabism movement related to the Sunni Islam, too, is rooted in Saudi Arabia in the 18th century, and spread in the Arabian Peninsula. It is also based on the ultra-orthodox Islam, encourages and strengthens the Islam fundamentalist groups, but do not have jihadist groups. There are still Wahhabist schools in Saudi Arabia.

The Sharia law based on the fundamental Islam is a moral code and a legal framework for those who live under the Islam. In most of the countries, where the majority of the population is Muslim, the Sharia law was introduced. The Sharia law is inconsistent with the freedom of religious, the equality between men and women, the freedom of speech and the secular state. It regulates public and private life, such as politics, economic, business, sexuality, and social issues, such as diet, prayer, etiquette, and fasting. It has a marriage law that regulates the marriage, i.e., who and under what conditions can marry the other, penalties for the theft, which can be imprisonment or amputating hand or feet. Two eyewitnesses are required the theft to be proved. The adultery is punished with 100 lashes if committed by unmarried persons, but with stoning to death if they are married. This crime requires four man eyewitnesses in order to be proved. The women should be at home, cannot be educated, or work, participate in political and social life, and have to wear chador.

The source of the Sharia law is the teaching and practices of the prophet Muhhamad who interpreted the Quran in the Sunna, so, does not accept the state law. The Sharia court will pass a sentence, when Sharia law is violated. Principles of the Sharia law are totally against the Western constitutional human rights, such as the freedom of individuals, equality, proportional punishments, fair criminal trial, etc.

Because the fundamental Islam interpret the Quran and the teaching of Muhhamad literally, it has become intolerant in the daily matters, violent, fanatic to other cultures and religions, authoritarian in the politics and exclusive in the scientific issues. It has led to the hostility with the Western countries, especially the US and Israel, called them as the "big devil" and the "small devil”. It rejects even the Western dressing, such as necktie, short skirt, low-cut dresses, and the Western forms of communication, such as laughing, handshaking, salutation, applause, etc.

The Islamic fundamentalism announces the necessary of the Islamic revolution, which requires political and social actions. Violence as a tool of the Islamic revolution is allowed against the non-Muslims, and terrorism has been justified just with this goal: to bring the whole world to be under the Sharia law.

The fundamentalist Islam reopens the gate of jihad in this way, in the form of the holy war against the enemies of the Islam, who do not believe Allah. Those who follow jihad are called mujahid. Jihad has been considered by the most of the interpreters as a religion duty of the Muslims to struggle in the way of Allah, often by a holy war, which is an armed struggle. Jihad has increasingly been a military issue during the last decades.

\section{The Role of the Islamic Fundamentalism in North Africa}

The characteristic of the terrorism has different features in the West, in the Middle East, and in the North African countries.

The Western countries have to face with the global terrorism, especially with Al Qaeda, such as the terrorist attack of 9/11, in Madrid and London, and the so-called lone wolves, who grew up and educated in the Western countries, but radicalized by the influence of the extreme ideologies advocated by imams in Islamic 
mosque, or in the internet ${ }^{16}$. The international cooperation among the international organizations, such as NATO, UN, and EU (European Union), and the intelligence of these countries has had sufficient successes in this field during the last decades.

The Islamic fundamentalism has been rooted in the Middle East. In the Political Violence and Terrorism Risk Index, the Middle East is in the worst severe category, together with North Africa. There are hostilities between the Sunni and Shiah, there are state sponsored terrorist groups, such as the Al Qaeda formerly supported by Afghanistan and Sudan, the Hezbollah by Iran, Syria, and Lebanon. The Hezbollah has become "the state in the state", a quasi state authority in South Lebanon, having legislation, public administration, and jurisdiction. More terrorist groups, such as the Hamas, the Fatah, and the PLO (Palestine Liberation Organization in the area of Palestine National Authority) have been expanded in the public authority system controlled by military administration. A special increase of the terrorist attacks can be seen in the cases of state disintegration, such as in Iraq, Afghanistan, and Syria, which let the infiltration of the terrorist groups in the state system. The other reason of the high terrorist attacks in the Middle East is the Israeli and Palestine conflict. Primarily the Al Qaeda has been related to the global terrorism, insisting on the establishment of the World Caliphate.

The Islamic religion is dominant in North Africa, and on the Eastern coast of the continent. In the countries examined by the study, there are Christians only in the southern part of Ethiopia, Sudan, Chad, Nigeria, and Mali (see Figure 10). If we consider the map on the political violence and terrorism risk, and the Terrorism Risk Index, we can make the conclusion that terrorism and political violence are especially high in the most Islamic countries in North Africa and the Middle East ${ }^{17}$.

The question may arise if there is any relationship between the terrorism and the Islamist extremism? As mentioned above, Islam is the typical religion in the world currently, which has an extreme branch, the fundamentalist Islam that is based on violence. However, there are Islamic countries, such as Saudi Arabia, Turkey, Morocco, e.g., that are not really infected by the terrorism related to Islamist extremism, or the terrorism is extremely high the middle of Africa, where Christian and local religions are typical, and where the Islamic extremism has little effect ${ }^{18}$.

The next issue to examine is that in which African countries have the tradition of the fundamentalist Islam, or, have been widespread in the last decades?

The Muslim Brotherhood was rooted in Egypt, committed many assassinations and bomb attacks between 1940 and 1980. The recent terrorist groups, the Al-gama’a ad-Islamiyya and the Egyptian Islamic Jihad (established by Ayman Al-Zawahiri) in the name of jihad implemented robbery, killing, bombings, insurgency against the Christian copts in Egypt, Jewish in Israel, but against the police, government offices, and high level state officials, presidents, too. The Egyptian Government tried to suppress the terrorist groups by harsh law enforcement: imprisonment, torture, and execution. The poor and the lower middle class still support the fundamentalist Islam, which was proven by the fact that during the Arab spring in Egypt in 2011, Morsi who was supported by the Egyptian terrorist groups won the election. The Sharia law was acceptable even in 2012

\footnotetext{
16 Tomolya, Janos. (2012). Challenges of terrorism. Art of War (Hadtudomány) MHT Publ, 22(3-4), 34-36.

17 Chikni, Lamine, \& MacDonald, Myra. (2013). Al Qaeda’s widening North African jihad confounds foes, pp. 1-2. Algiers/London.

18 Dowd, Caitriona, \& Raleigh Clionadh. The myth of global Islamic terrorism and local conflict in Mali and the Sahel, pp. 1-12. African Affairs Advance Access published May 29, 2013. Oxford University Press on behalf of Royal African Society.
} 
by the $75 \%$ of the population, however, the traditional form only by $20 \%$. The new constitution proposed by the Morsi government, had several provisions on the Sharia law.

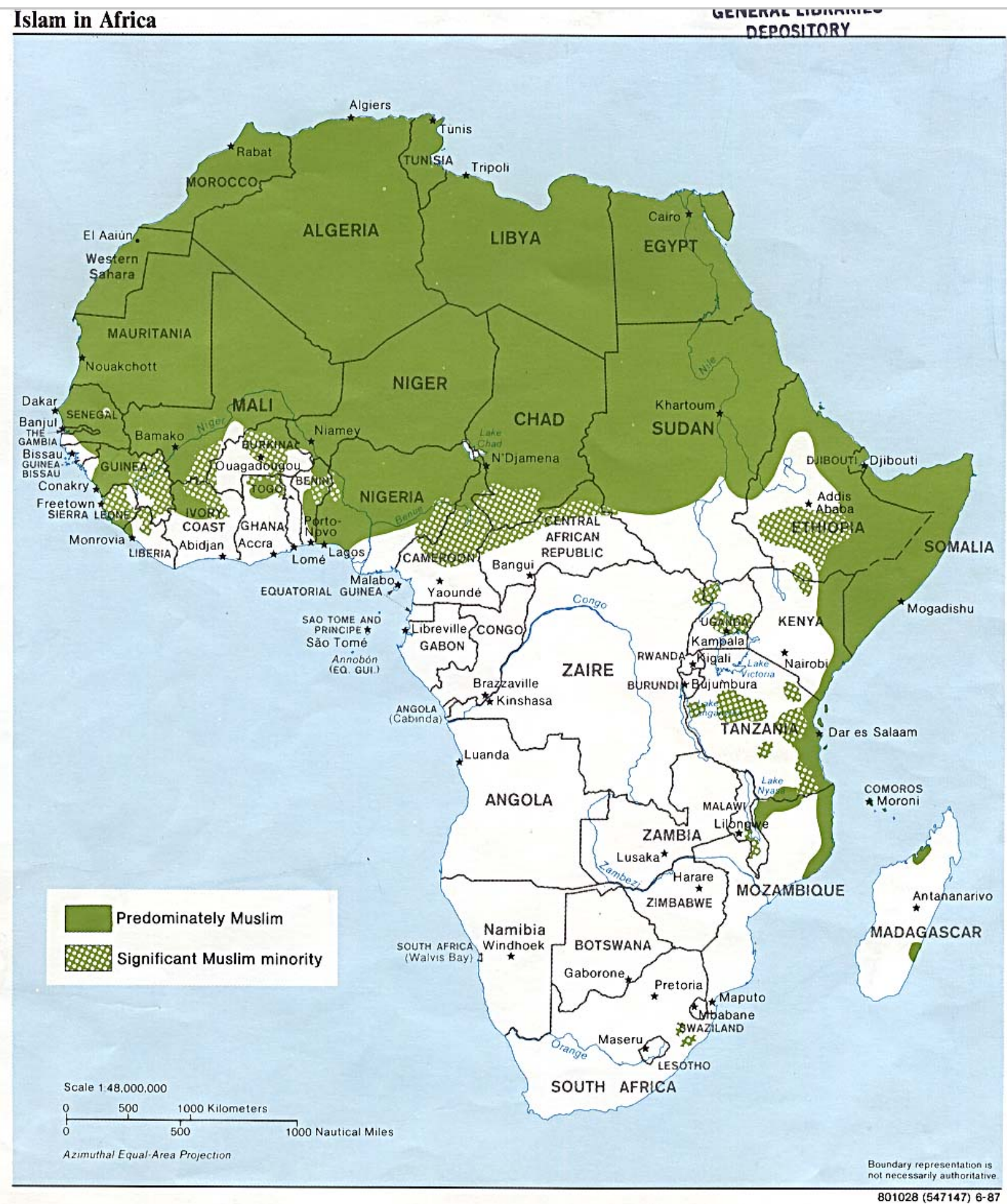

Figure 10. Islam in Africa ${ }^{19}$.

${ }^{19}$ University of Texas. (2003). Islam and Africa. Retrieved from http://islam.uga.edu/countries.html. 
The Islamic fundamentalism did not have sufficient traditions in Tunisia, because the Ben Ali government had already introduced the secular state in 1987 so that Islamic fundamentalism should be suppressed. As the result of the "Jasmine Revolution", the opposition party won the election in 2011 and the Marzouki government declared the secular state again, prohibited the Sharia law, and launched certain human rights, such as the equality of the women, freedom of religion, and economic constitutional rights, as well. Salafist movement has emerged in Tunisia after the revolution in 2011, as a reaction to the prohibition of every manifestation of the Islam fundamentalism by the former Ben Ali government. The spots of Ansar al-Sharia appears, too, but did not have serious influence in the country, especially not in the form of terrorist attacks. "Only" four terrorist attacks, the least in North Africa, occurred here since 9/11.

Libya, during the Gaddafi regime sponsored more terrorist attacks, and for this reason, UN sanctions were implemented in the country. However, the Gaddafi regime tried to suppress the spread of the fundamentalist Islam. Two Islamist terrorist groups were created during the civil war in Libya both of them belong to the $\mathrm{Al}$ Qaeda. The Ansar al-Sharia created during the civil was in 2011, and was involved in the terrorist attack in Bengazi in 2012. At the moment, it operates in the northern part of the country. The Ansar al-Sharia tries to infiltrate in the Libyan state system, e.g., offers social programs, agrees with militias, etc. The country is, however, controlled by Islamist and criminal militias, and the government is too weak to strengthen the central state power. There are many Islamist state officials in the new Libyan Government close to the Salafist Islamic extremists who advocate introducing Sharia law in the country. The AQIM, basically connected to Algeria, was formed in 2007 and operates on the southern part of Libya, commits terrorist attacks here, as well. The number of the terrorist attacks is relatively low—seven, since 9/11 in this country.

In Morocco, the Islamic fundamentalism did not have any tradition, and no Islamic terrorist group can be found here. Relatively few, nine terrorist attacks happened here since 9/11, too.

The Western Sahara, despite its vague international law status — annexed by Morocco in 1975, had a war here until the ceasefire in 1991, at the moment forms part of Morocco as a non-self-governing territory, but controlled by the Polisario Front, which is a rebel nationalization liberation movement, the area have not recognized yet by any UN nation in this status, but was suggested to hold a referendum to decide if to belong Morocco or will be an independent state - and the refugee camps in Algeria have not been in a chaos, much more represent a good governance. The Sahrawi—-the ethnic group of West Sahara—living not just in West Sahara, but as refugees in the South West Algerian refugee camps, are controlled by the Polisario Front, but the Algerian Government does not intervene in their local matters ${ }^{20}$. The Sahrawi had the tradition of secularism and religious tolerance, and the Polisario Front did not have any relationship with the terrorist groups. Some analyzer supposes that the MUJAO (Movement for Unity and Jihad in West Africa) located around the area of Sahrawi refugee camps, can successfully recruit members from the youth of Sahrawi, but there is no tangible prove to $\mathrm{it}^{21}$.

Algeria, which has a stable and authoritarian state with strong military since its independence, during the 1970s, the Bendjadid government attempted to establish Arab style society and public life. Teachers from Muslim countries were invited who spread the radical Islam in the schools. This tendency was fastened with the return of the Algerian jihadists from Afghanistan. Social unrest upheld during the 1980s, and resulted in a

${ }^{20}$ Fiddian-Qasmiyeh, Elena. (2011). The pragmatics of performance: Putting “faith” in aid in the Sahrawi refugee camps. Journal of Refugee Studies, 24(3), 1-15.

${ }_{21}$ Alexander, Yonah. (2013). Terrorism in North Africa and the Sahel in 2012: Global reach and implications. P. 4. Inter-University Center for Terrorism Studies, Potomac Institute for Policy Studies, Arlington, VA 22203, February, 2013. 
multi-party system by 1991, when the FIS won the election. The FLN dominated the government since the independence of 1954 in the country, cancelled the election and banned the FIS. A harsh civil war was broke out between the FIS and the FLN, and ended only in 1999.

The GSPC formed at the end of the 1990s, fought against the Algerian military in order to establish an Islamic state. The Bouteflika government tried to make a national reconciliation by amnesty, but was not successful in its effort: The Islamic fundamentalism still prevails in the form of terrorist groups. It is the case in spite of the fact that the Algerian Government has a strong military and an efficient counter-terrorist strategy.

The GSPC later became the AQIM that is also based on the Salafist-jihadist dogma ${ }^{22}$. The AQIM had 30,000 members that were reduced by 1,000 due to the counter-terrorism efforts of the Algerian Government. Eighty-eight percent of the AQIM operates in North and South Algeria, but some of them in North Mali, in South Libya, South Tunisia, and South Mauritania. The AQIM perpetrates terrorist attacks in the neighboring Sahelian countries, such a Libya, Tunisia, Mauritania, Niger, and Mali, as well, and have financial resources from kidnapping for random, smuggling cigarettes, narcotic, and drug. It established links with Latin American cartels in smuggling drug and weapons.

The AQIM's leader Mokthar Belmokhtar, the one-eyed “Marlboro man” was killed in 2013, cooperated with the AQAP (Al Qaeda in Arabian Peninsula) in Yemen, the Boko Haram in Nigeria, and the Al-Shabaab in Somalia, and played a dominant role in the insurgency in 2012 in North Mali.

MUJAO, a jihadist group, located in South-West Algeria, broken off from AQIM and perpetrated car bombings and kidnaps in South Algerian and North Mali. In 2011 and 2012, the MUJAO abducted three humanitarian workers form the refugee camp in Tindouf, South West Algeria, and seven Algerian diplomats in Mali, and perpetrated two terrorist attacks in Algeria.

There have happened extremely high terrorist attacks, 1,234 in the country since 9/11. This is as high as in Somalia, Nigeria, and Sudan, but 20 times more than in Chad that is the worst category in the Sahel. There is no clear explanation to this, because the Algerian Government has directed a most effective counter-terrorist strategy in North Africa. The only reason could be that the AQIM, the strongest and the biggest terrorist group in North Africa has been localized primarily in Algeria, and spread in less extent in the neighboring countries.

The area of North Mali, bordered by Algeria and Niger has been the most important and best safe haven for the AQIM and its affiliates. However, the number (54) of the terrorist attack is much less than in Algeria. This was rather a safe haven for the terrorist groups, because this area is a vast desert, uncontrolled by the Mali Government, which has a weak military, furthermore a semi-nomadic tribe, the Tuareg live here. Mali otherwise has not have tradition or influence of the Islamic fundamentalism until this time. The terrorist groups led by the AQIM here, perpetrated suicide bombings, car bombs in Algeria, Niger, and Mali. Their aim is to attack Western targets, such as foreign workers, officials, embassies, military basis, etc.

In Mali, a rebellion was launched in 2012, when the Tuareg tribe, an ethnic minority in the country represented by the MNLA (National Movement for the Liberation of Azawad) took control of the north of Mali and declared independence of Azawad. The AQIM and its splinter groups, the MUJAO in West Algerian and the Ansar al-Dine, the latter one was established in Mali in 2012, supported by the Tuareg. These terrorist

\footnotetext{
${ }^{22}$ Harmon, Stephen. From GSPC to AQIM: The evolution of an Algerian Islamist terrorist group into an Al-Qaida affiliate and its implications for the Sahara-Sahel region. Pp. 12-22. Concerned Africa Scholars, Bulletin N 85, Spring 2010.
} 
groups marginalized the Tuareg then, and introduced the Sharia law in this area. The Tuareg were forced back by the French military, but the terrorist groups are still at present sporadically in the area ${ }^{23}$.

In Mauritania, there was no tradition of the Islamic fundamentalism. The county has to face the problem of being the neighbor of Mali and Algeria, where the terrorism is extremely high, and can easily cross the borders in the form of kidnapping and smuggling. Twenty-seven terrorist attacks were perpetrated here since 9/11.

In Niger, however, there was a Wahhabist religious uprising in the capital 30 years ago, there is no tradition of the Islamic fundamentalism, because the state was secularized and the religious tolerance became determining. Two Tuareg rebellions occurred here in 1999 and 2007. There is still a danger in Niger, too, that the AQIM and its affiliates will infiltrate in the Tuareg tribes, and will be infected by the radical Islam. The most important danger is the cross-border terrorist attacks which aim to disintegrate the local governance and attack Western targets. The authorities of Niger, with the help of the international community, have strengthened the Northern part of the country, and its border, as well. Relatively high terrorist attacks, 39 terrorist attacks have happened here since 9/11.

In Chad, however, 58 terrorist attacks occurred since 9/11, there is a sufficient counter-terrorism strategy. Chad does not have a tradition of Islamic fundamentalism, only a small minority has been the follower of the Salafi Islam. Terrorist groups do not operate here.

In Ethiopia, there is no tradition of Islamic fundamentalism, either, and the number of the terrorist attacks since 9/11—only four, perpetrated by the Al-Shabaab along in the eastern border with Somalia.

Nigeria has a long tradition of the Islamic fundamentalism. On the northern part of the country, where the Muslim population lives, a sovereign sultanate existed in the middle ages, and the Sharia law was applied since centuries: Alcohol was prohibited, homosexuality, infidelity, or theft was harshly punished by amputation, stoning to death, and lashing. The Miss World pageant in 2002 led to a riot in the north, with many dead and injured. During the last decades, the Islamic fundamentalism had followers in the northern part of the country, establishing groups that tried to influence the population by establishing mosques and schools for the poor children, where the Islamic fundamentalist ideas were taught. Researchers confirm that the ideologists of the Islamic fundamentalism could successfully influence the poor and unemployed youth arguing against state corruption, organized crime, such as drug trafficking, piracy, and also, for the social unrest.

Boko Haram, the Islamic fundamentalist, jihadist terrorist group was formed in 2002, to abolish the secular state and introduce the Sharia law in the whole country. The Boko Haram has implemented the Sharia law in most parts of the country in north, and perpetrated terrorist attacks, as well, and has resulted 10,000 dead until this time. It attacks Christians, government offices, churches, schools, kidnaps foreign tourists, and assassinates even the Muslims who criticize them. It is thought by some analyzers that the Boko Haram has a relationship with the AQIM, but there is no reliable evidence to its international network. The Boko Haram rejects any relationship with the Western, such as education, work, lifestyle, etc., has been closely related to the organized crime, and increasingly became a military group.

Since 2009, the Boko Haram has been pursuing a harsh fight with the police and the military that has used even air strike and blockade against them. The authorities of Nigeria has not been successful to defeat the Boko Haram until this time, however, they ask the help of the international organizations and the foreign countries.

\footnotetext{
${ }^{23}$ Arieff, Alexis (2013). CRS Report for congress: Crisis in Mali, pp. 1-13. Report of Congressional Research Service, Library of Congress Publ. 2013. Washington, D.C.
} 
Sudan and Somalia, in the horn of Africa, represent the same region, forms a political, economic, ethnic, religious, and cultural community with the Middle East ${ }^{24}$.

Sudan has a tradition of Islamic fundamentalism due to the wide spread of the Salafi Islam. As mentioned before, Sudan did not have any democratic government, just military juntas and dictatorships since its independence. Colonel Omar al Basir, who acquired the power in 1989, implemented an extreme dictatorship, and established the National Islamic Front, the only political party in the parliament. Sharia law was introduced in 1983 in the northern part of the country, regardless of being Muslims or not, who were under the force of the Sharia law. Sudan became an autocratic, single-party Islamist state. During the 1990s, an Islamist politician, Hassa al Turabi began to support the Islamist fundamentalist groups, and invited Osama bin Laden to the country $^{25}$. The government supported the Lord's Resistance Army, the religious (sect-based) extremist military group that operated in South Sudan, Uganda, the Central African Republic, and the Democratic Republic of Congo. Also, it established a good relationship with Iran and the former Iraq ruled by the Saddam regime. Sudan was listed on the state sponsors of the terrorism, and was bombed by the US in 1998. The Sudan Government tried to dissolve the international isolation and expelled some terrorist groups from the country, and also, sent Bin Laden away. In 2010, al-Basir was reelected by an anti-democratic and unfair election in spite of the international arrest warrant issued by the International Criminal Court. The northern part of the Sudanese state remained Islamic fundamentalist.

In Somalia, where the Wahhabist Islam has tradition, the ICU, an Islam fundamentalist group controlled the Southern part of the country by the beginning of the 1990s, when the Siad Barre regime collapsed. The ICU consisted of only judges, and structured by several courts with legislation, public administration, and jurisdiction functions. The ICU was supported by some local landlords and the local population, as well. The religion of the most of the population in Somalia is Sunni Islam. The ICU fought guerilla warfare with the army of the TFG. The ICU introduced the Sharia law and established Sharia courts, as well. These courts functioned as providers of public services, such as health care, education, police, etc., regulated the public and private life, banned the drugs, Western movies, music, football, etc. These courts emerged during the 1990s, merged in the form of a militia, and tried to occupy the territory of the country. The government could squeeze out the ICU from the capital and the other part of the country by the help of the US, and captured their members. Many of them escaped to Eritrea that supported the ICU during the war. The ICU supported by the Al Qaeda, implemented bombings, such as in Kenya and Tanzania in 1998. In 2006, the ICU began to fight with the other groups of landlords that demanded secularization in the capital, Mogadishu.

The ICU won, controlled the capital and the area around, and could acquire most of the weapons in the country. The capital fell into a chaos. More and more areas were captured by the ICU later, and piracy along the coast was supported, as well. Ethiopia intervened with its army, and began a war with the ICU. The ICU announced a jihad and called jihadists from other countries to help them. As a result of the war, the ICU lost a lot of area in the country, withdrew from the capital and capitulated. The US and the UN intervened with air strike against the supposed Al Qaeda members. The members of the ICU had to hide in the country, however, the ICU still exists, but other military groups, such as the Al-Shabaab split from the ICU, and continued the war

\footnotetext{
${ }^{24}$ Harberson, John. (2013). The war on terrorism in Africa, p. 24. Princeton N. Lyman, Western Press.

25 Islamic movements in Northern Africa-Islamic fundamentalism in Africa and implications for U.S. policy. Pp. 1-3. Retrieved from http://www.danielpipes.org/218/islamic-movements-in-nortehrn-africa.
} 
against the government. The 95\% of the members of Al-Shabaab are located in Somalia ${ }^{26}$.

By 2009, the Al-Shabaab which declared its close relationship with the Al Qaeda, still controls the southern part of the country and is supported by several landlords here, too. The Al-Shabaab has continued global jihadist war and perpetrated many terrorist attacks in other countries, such as Kenya in Nairobi, too, primarily against Western targets, and acquires its financial support from piracy. Although, a federal republic with a new constitution was established in 2010, the central government in Somalia is still weak, no one government can keep the governance for a long time, the prime ministers are changing all the time. This power vacuum has been successfully used by the Al-Shabaab.

\section{The Relationship With Islamic Fundamentalism and the Terrorism}

On the basis of the analyses above, we can make more conclusions. The most important is that the tradition of the Islamic fundamentalism can directly lead to the escalation of terrorism in these countries regardless of the state is stable, weak, or collapsed.

Egypt, although it always used to be a stable autocratic presidential state, could not cope with the terrorist group, the Islamic Muslim Brotherhood and its successors, the Egyptian Islamic Jihad and the Al-gama'a ad-Islamiyya, either in the second part of the 20th century, or at the beginning of the 21th century, even if implemented harsh law enforcement. The party represented by the Islam fundamentalists, won the democratic election in 2011, and only the military could overthrow the Morsi government in 2012. This is because the Islam fundamentalism is deeply rooted in the population of Egypt.

Algeria can be mentioned as another example to the spread of the radical Islam-based terrorism, in spite of the fact that it has been a stable autocratic state with a strong military until this time. Similarly to Egypt, the GSPC, the Islam fundamentalist party that won the democratic election in 1991, could be able banned only by the cancellation of the election, which led to a civil war, and the secular government won finally. The radical Islam, however, was so strong in the population that the government could not hinder the evolution of the strongest terrorist group of the region-the GSPC, later its successor, the AQIM and its affiliates, such as the MUJAO and the Ansar al-Dine. Most of them are related to the Al Qaeda. It is another matter that these terrorist groups spread to the neighboring countries, especially to Mali, where found a safe haven. The centre of the radical Islam-based terrorism in the Sahel has been rooted in Algeria.

The northern part of Nigeria has also a long historic tradition of Islamic fundamentalism: The Sharia law in the most extreme form has already existed here since centuries. This area infected by the radical Islam, has been a hotbed for the Boko Haram further strengthened with the weak, corrupt, and illegitimate state which police and military cannot defeat the Boko Haram, but seems to have a hopeless fight with them.

In Sudan, a dictator al Basir acquired its political power by coup-d'etat, and introduced the radical Islam in the form of establishing the National Islamic Front, the ruling party in the parliament, and established good relationships with the terrorist state sponsors, as well. The Salafist Sunni Islam has tradition among the Arabic population of the country. The radical Islam government, the al Basir government could keep its power in the northern part of the country and controls this area, even after the rough civil war with the non-Arabic population and the breaking with the southern part of the country.

The reason why the ICU and its successor, the Al-Shabaab could find allies in Somalia was that some

\footnotetext{
${ }^{26}$ International Crisis Group. (2014). Somalia: Al-Shabaab-It will be a long war. Africa Briefing No. 99. Nairobi/Brussels: International Crisis Group.
} 
landlords supported the radical Islam. The ICU occupied almost all the territories of the country and was not far from establishing a fundamental Islam state in Somalia. The Somali state is still too weak to take successful actions against the jihadist war of the Al-Shabaab.

In the above mentioned countries, the escalation of the terrorist groups was more or less related to the tradition of the radical Islam in the population. The evident difference between the strong and stable states vs. weak or collapsed states in their counterterrorism efforts is that the strong states, such as Egypt and Algeria can successfully hinder that the terrorist groups can infiltrate in the state authorities, and exclusively control an area, or in the worst cases, establish a state based on the Islam fundamentalism. The stable states can decrease the number of the terrorist attacks, and can expel them out of the country, like it happened in Algeria and Egypt.

\section{The Strong or Weak Central State and Local Government vs. the Terrorism}

The central state and the local government, as we referred to in the former chapter in the study, could be strong or weak for more reasons: ineffective law enforcement (police, intelligence, military, jurisdiction), violation of human rights caused by ethnic $\operatorname{conflicts}^{27}$, or the autocratic feature of the government, little capacity to control the unpopulated, or tribal areas, and its borders. In a collapsed state, these functions do not operate at any level. The study will examine in this chapter if these factors are related to the terrorism, and if so, how determined the spread of the terrorism in the North African countries.

Egypt has always had a strong state apparatus and military, but violated human rights during the autocratic presidencies. This led to the revolution of the opposition in 2011 that demanded more democratic governance. The terrorism developed in this country since the middle of the last century, does not connect with the autocratic feature of the government, much rather, as we have already explained, with the tradition of the Islamic fundamentalism.

Libya, as mentioned earlier, was an extreme dictatorship during the Gaddafi regime, which suppressed the conservative Islam movement. After it had collapsed due to the revolution in 2011, the state disintegrated, and the military of Gaddafi was defeated, but was not reestablished yet. The Libyan Government does not have efficient military or law enforcement, consequently, the radical Islam-based militia, the Ansar al-Sharia can infiltrate in the state system, and tries to control the country. The Justice and Construction Party influenced by the Muslim Brotherhood, has 17 seats from 80 in the parliament. The desert areas of the Southern and Eastern parts of Libya are not controlled by any state authority, so it serves as a safe haven and place of terrorist attacks perpetrated by the AQIM and the Ansar al-Sharia.

Algeria has a desert and a rocky mountain area in the Southern and Western parts of the country, which cannot be sufficiently controlled by the state authorities. This is ideal for the AQIM and the MUJAO. Not accidently, the terrorist attack in Amenas in 2012 occurred in the desert area, close to the Libyan border. The MUJAO has found a safe haven in the western part of Algeria, but cannot control the Sahrawi refugee camps, due to the good governance, among others- the secular and religious tolerance character of the Polisario Front. The worst that the terrorist groups can do is to recruit members from the youth.

The AQIM implemented terrorist attacks in South Tunisia, too, in the desert area, but could implement a relative few terrorist attacks in the country.

\footnotetext{
${ }^{27}$ Vandyke, Matthew. (2012). Mali, Sudan, and ethnic conflict in Northern Africa, pp. 1-6. Retrieved from http://www.
} matthewvandyke.com/blog/mali-sudan-ethnic-conflict-north-africa/. 
Morocco has an effective counter-terrorism strategy, and does not have any factors, such as inefficient police, military, human rights violation, non-stabile state, nomadic or desert area, etc., that could be the hotbed of the terrorism here, except West Sahara, but it is sufficiently controlled by the Polisario Front.

Mauritania has serious problems with the human rights and ethnic violence. In 1989, there was a harsh civil war between the Moors in north and the Black in south, due to the tension caused by ethnic discrimination of the government. Seventy thousand black people were expelled to Senegal by the end of the civil war. Human rights are still seriously violated in this country. Although, the slavery was abolished in 1981, the antislavery law has not been enforced by the government. The $20 \%$ of the population are still enslaved, which is reasoned by the poverty of the population and the lack of labor opportunities. Female genital mutilation, child labor, human trafficking are widespread. Ethnic violence often happens against the black who do not have equal rights with the Arab-Moor population. Mauritania has a relative weak government that cannot control the border areas along Algeria and Mali, so the terrorist groups can implement terrorist attacks here.

As mentioned earlier, Mali has been the most important safe haven for the AQIM and its affiliates, such as the MUJAO and the Ansar al-Dine. The Toure government could establish stability since 1991, due to the democratic processes, but the weak military could not cope with the Tuareg insurgencies that claimed independency. The area of the country was an ideal place for the terrorist groups, because being a tribal and desert area, was less controlled by the central government, and the insurgency of the Tuareg in 2013 gave an opportunity for them to infiltrate in the Tuareg groups during the rebellion in order to control the area later.

Niger, similarly to Mali, has to face the danger that the AQIM and its affiliates will infiltrate in the Tuareg tribes that have already broken out two rebellions in Niger, too, and the government cannot control the tribal areas of the Tuareg. However, counter-terrorism efforts were implemented in the country in order to avoid such a situation with the terrorist groups. Similarly to Mauritania, the weak government in Niger cannot hinder the cross-border terrorism from Algeria and Mali.

The dominant rule of the Boko Haram in North Nigeria is closely related not only to the tradition of the radical Islam here, but the insufficient operation of the state authorities, as well. Serious ethnic tension arose and ethnic violence occurred between the Muslims in north and the Christians in south, as a result of the ethnic discrimination. Human rights have been seriously violated by the military and the police, in 1966 and 1970, too, when the two civil wars broke out. The ethnic violence on the area of the Niger Delta for the control of the oil production has been at present until this time. The police of the military junta rape, torture, execute, cruelly treat, and unlawfully detect the people who participate in these conflicts. The organized crimes in the country have not been hindered, either: human and drug trafficking, prostitution, forced labor, child labor, and piracy flourish. Such a corrupt state will evidently not be devoted in the counter-terrorism, either.

Chad is also typified by the human rights violation, such as polygamy, abuse in the family, female genital mutilation, etc. There are nomadic tribe areas in the countries which are not controlled by the weak central state authorities. The history of Chad has seen more rebellions, civil wars and coup-d'etat, military junta and dictatorship. The country has been infected, but not in a great extent by the terrorism due to the inefficiency of the state, however, it tries to defense its territory from the terrorism.

Ethiopia has a legitimate government with strong military, and despite of the poverty in the country, can successfully control its area from the terrorism. 
Sudan has been a failed state with inefficient state functions, such as military, police, legislation, jurisdiction, public administration, due to the rule of the fundamental Islamic government. The worst version occurred in Sudan: The radical Islam groups could acquire the state power, eliminating the basic functions of the efficient state, but based them on the Sharia law and the influence of the terrorist groups.

The central government in Somalia has still little power to operate the basic functions of the state, too, especially lacks an effective military and police. It still cannot control some areas in order to expel the terrorist groups from the country, prevent the terrorist attacks, and cannot cope with the armed conflicts among the landlords, either.

The conclusion can be drawn on the basis of the analyses above that the lack of strong central government with inefficient military, police, law enforcement, existence of harsh human right violations, ethnic and religious hostilities and tensions, inefficient control over the territory and the border of the state can be a hotbed of the terrorism. There are, however, no automatic and uniform links between these factors and the terrorism.

Those countries have been the mostly threatened by the terrorism where the state has collapsed or weakened in such a great extent that the non-state actors, such as militias, rebellion groups, landlords, etc., has taken over the power to control the population. We can mention Libya, Mali, and Somalia as examples to it.

In Sudan, the illegitimate government itself established an Islamic fundamentalist state, and as opposed to Egypt and Algeria, the tradition of the checks and balances in the state system that could have overthrown such a government had not developed, because the history of the country saw only dictatorships. The non-Arabic, black population in South Sudan could be released from this situation only by a cruel civil war with suffering genocide.

Nigeria can be considered special in this context. As opposed to other weak states in the Sahel, such as Mauritania, Mali, Niger, Chad, and Ethiopia, the government in Nigeria has been so corrupt that similarly to other public problems, such as organized crime, human rights violation, ethnic tensions, etc., did not direct too much effort to cope with the terrorism in North Nigeria. The other weak states in the Sahel have cooperation with international organizations, and the Mali government called the French army, too, to help them against the Tuareg rebellion, to establish a counter-terrorism strategy.

\section{Public Tasks, Transparency, Accountability, Management of the Internal Conflicts vs. Terrorism}

The economic and social problems have been typical in North Africa, but the difference between the countries is the extent the states here have to face with $^{28}$.

It is general phenomena in the countries of the Maghreb that after the independence from the colonial state in the middle of the last century, the national industry was nationalized, no matter it was a socialist state under the influence of the former Soviet Union, or not.

In Egypt, the Nasser government, under the communist influence of the former Soviet Union, could implement successful land reform, economic development, social mobility, and a better education. The Gaddafi regime in Libya could assure social security, housing, and education, too. The same happened in the socialist Algeria. The Tunisian Government was not successful in this effort.

\footnotetext{
${ }^{28}$ H. Cordesman, Anthony, \& Nicholas S. Yarosh. (2012). The causes of stability and unrest in the Middle East and North Africa: An analytic survey. Center for the Strategic and International Studies. CSIS Publ. Washington, D.C. Retrieved from http://www.csis.org.
} 
During the 1970s, there was tendency toward the liberalization of the economy in Egypt, Algeria, and Morocco, which meant privatization of the state-owned enterprises, support of the foreign investment, and reducing taxes in the business sphere. By the beginning of the 2000, the economic and social problems became widespread in the Maghreb, which together with the expectation to a more democratic government-led to the Arab spring in these countries. Poverty, high unemployment, especially in the youth (in Tunisia and Egypt, it is above 30\%), social inequality, shortages in housing, and high inflation were widespread.

As mentioned earlier, a democratization process began in these countries due to the unrest of the Arab Spring, but was successful only in Tunisia, Algeria, and Morocco, where the government on power was capable to manage the situation and make a compromise with the opposition to meet their requirements in democratic, economic, and social matters. Egypt will probably be able to cope with these economic and social problems, as soon as it solves its political matters. Libya seems to be problematic from this point of view, due to the collapse of the state.

With one exception of Libya, it cannot be said that the economic and social problems would be connected to the increasing terrorism in these counties. The GDP in Algeria and Libya is the highest one, between $\$ 4,000$ and $\$ 12,000$, in Morocco, Tunisia, and Egypt, the GDP is between $\$ 2,000$ and $\$ 4,000$. These countries should be considered as fairly wealthy.

The countries in the Sahel are known as extremely poor with very low level of public services. The Sahel is the home of more than 50 million people, who are the poorest in the world. The GDP in these countries ranges only from $\$ 200$ to $\$ 700$. The majority of the population here lives in rural areas and works in the agriculture. They are often nomadic or farmers. Even the basic public services, such as water supply, electricity, canalization, trash collection, roads, elementary education, health care, employment programs, etc., have not been provided by the governments. The literacy rate is the lowest one of the world in the Sahel, less than $30 \%-40 \%$ of the population. Disasters, such as floods, starvation, draught, desertification, water scarcity, demographic pressure, AIDS, etc., are the highest in the Sahel.

This is the case even in those countries, such as Nigeria, Chad, and Sudan, where the rich natural resources could serve as a base for the improvement of the rural areas. As it was explained earlier, the financial resources of the states are not generated to the increase of the living standard of the people, but for the private goals of the politicians and the high level public administrators.

The Corruption Index shows the effect of corruption at the level of how the governments can cope with the economic and social problems. Besides Somalia, Sudan, and Libya, where the governments do not, or cannot care about public tasks, due to the disintegration of the state authorities, and where the corruption is extremely high, Nigeria has been on the top among these countries. The rest of these countries in North Africa are in the four worst of the 10 scales. Integrity, openness, the unbiased jurisdiction, and the independent controlling authorities lack in a great extent, in North Africa.

The public goals, such as managing public problems, providing public services, can be followed only in those countries that are based on pluralism. It means that the several social groups can express their interests in a pluralist system. It is especially problematic in the poorest African countries, where the population of rural areas does not have any opportunity for this. There is no economic development, proportional taxation, fair redistribution, education, welfare, employment, infrastructure public services in these areas.

However, there is no direct relationship between the unsolved public tasks and the terrorism. There are sufficient efforts to elaborate a counter-terrorism strategy even in the poorest countries, such as Mauritania, 
Mali, Niger, Chad, and Ethiopia. Only one relationship in this matter can be mentioned: The poor, uneducated youth who do not have any chance to develop their life, can easily be recruited by the terrorist groups, because they are fairly responsive to the radical and extreme ideas.

The relationship between the mismanagement of the internal conflicts and the terrorism has been much more tangible since $9 / 11$. This is the reason why after $9 / 11$, the escalation of the internal conflicts have been the best hotbed of terrorism, such as occurred in Iraq, Afghanistan, and Syria, e.g., in the last years.

As the most evident example, Mali can be mentioned in North Africa, where the ethnic conflict with the Tuareg rebellion almost led to an Islamic fundamentalist state. The same problem with the Tuareg in Niger was better-managed.

The Boko Haram in Nigeria has been rooted, too, in the traditional religious conflict between the Muslims and the Christians, and the government has not done anything to reconcile them, neither had sufficient law enforcement and military forces against the Boko Haram.

In Mauritania, the serious ethnic conflict has not been used by the terrorists until this time. This is the case in Western Sahara, too, where the Polisario Front can manage the conflict between the Sahrawi population and the Moors in Morocco.

In Egypt and Algeria, however, the government had a long tradition to manage the conflict with the Islamic fundamentalists, has not had unambiguous results. The reason is that in Egypt, the former governments suppressed the Islamist groups with harsh law enforcement, and by coup-d'etat in 2013, and the cancellation of the election and the banning of the Islamist party led to a civil war in Algeria.

Sudan and Somalia can be mentioned as the worst example to the total mismanagement of the ethnic and religious conflicts. This is in a close connection with the increase of terrorism in these countries.

\section{Conclusions}

Regarding the main features of the terrorism in North Africa, we can make the conclusion that most of the terrorist groups have just a tight relationship with the Al Qaeda, but operate at national level, and do not emphasize the global jihad ${ }^{29}$.

The strongest terrorist organization is the AQIM that has affiliates in North Africa, but there is no real integration among them, they are much rather fragmented. There are countries, such Morocco, where there are only their small cells at present. Instead of the global jihad, they concentrate on the local authorities, such as military and police, or the civil population, e.g., kidnapping for random, taking hostages, and the income from organized crimes, such as human, drug, and tobacco traffic, and piracy. They do not have political identity, much rather try to use the ethnic-religious conflicts to marginalize them, then infiltrate in the state authorities. The power vacuum in the weak states and the less efficient counterterrorism efforts in the undemocratic states, the ungoverned territories in the desert, and tribal areas, or the religious belief of the Muslim populations and the poverty all serve as a gap to the flourish of the terrorism in North Africa.

Only the Al-Shabaab in Somalia has a strong connection with the Al Qaeda and aims primarily Western targets based on the global jihad.

On the basis of the study, the conclusion can be made that only the democratic governance, which means the multi-party system, respect of human rights, integrity, transparency, accountability, can assure the stability

${ }^{29}$ Boukhars, Anouar. (2013). Al-Qaeda’s resurgence in North Africa? Working Paper, Fride and Hivos Publ., Netherland, p. 14. 
and predictability of the state, which is essential in the counter-terrorism efforts. The unstable and collapsed state authorities have been the primarily factors - the most important hotbed of the terrorism.

The state has to have strong and efficient military, police, intelligence, law enforcement, and international cooperation in the field of counter-terrorism to combat against the existing terrorist groups in the region. It includes the control of uninhabited areas, such as the desert and the rocky-mountains, or the tribal areas, also, an effective border control. The terrorist groups can successfully use the power vacuum in the state.

The well-managed internal conflict caused by ethnic and religious hostilities, both by political means, such as reconciliation, amnesty, and military using modern procedures, has been an effective tool in the defense against terrorism. The terrorist groups can easily infiltrate in the rebellion groups and militias, then dominate them. The Islamic fundamentalism as a source of the religious tension has a high risk here, as well.

The unsolved economic and social problems, such as high unemployment, shortage of housing, poverty, and insufficient public services, could be the reason for the terrorism, too, because the unrest of certain social groups can lead to riots, rebellion, revolution, civil war, etc., that can undermine the integration of the state. The sharp difference between the wealth and the education of the social groups can make it easy for the terrorist groups to recruit members from here.

\section{References}

Alexander, Y. (2012). Terrorism in North Africa and the Sahel in 2012: Global reach and implications (p. 4). Inter-University Center for Terrorism Studies, Potomac Institute for Policy Studies Publ., Arlington, US.

Alexander, Y. (2013). Terrorism in North Africa and the Sahel in 2012: Global reach and implications. Inter-University Center for Terrorism Studies, Potomac Institute for Policy Studies, Arlington, VA 22203, February.

Arieff, A. (2013). CRS Report for Congress: Crisis in Mali. Report of Congressional Research Service. Washington, D.C.: Library of Congress Publ.

Boukhars, A. (2013). Al-Qaeda’s resurgence in North Africa? Working Paper. Netherland: Fride and Hivos Publ.

Chikni, L., \& MacDonald, M. (2013). Al Qaeda's widening North African jihad confounds foes (pp. 1-2). Algiers/London.

Cordesman, A. H., \& Yarosh, N. S. (2012). The causes of stability and unrest in the Middle East and North Africa: An analytic survey. Washington, D.C.: Center for the Strategic and International Studies, CSIS Publ.

Dempsey, C. T. A. (2006). Counterterrorism in African failed states: Challenges and potential solutions (pp. 1-4). Washington, D.C.: US Army War College, Strategic Studies Institute Publ.

Dowd, C., \& Clionadh, R. (2013). The myth of global Islamic terrorism and local conflict in Mali and the Sahel. African Affairs Advance Access published, Oxford University Press on behalf of Royal African Society.

Fiddian-Qasmiyeh, E. (2011). The pragmatics of performance: Putting "faith" in aid in the Sahrawi refugee camps. Journal of Refugee Studies, 24(3), 1-15.

Forest-Giroux, J. F., \& Giroux, J. (2011). Terrorism and political violence in Africa: Contemporary trend and a shifting terrain. Journal of Perspectives on Terrorism, 5(3-4), 1-7.

Harmon, S. (2010). From GSPC to AQIM: The evolution of an Algerian Islamist terrorist group into an Al-Qaida affiliate and its implications for the Sahara-Sahel region. Concerned Africa Scholars, Bulletin No. 85, Spring 2010. Washington, D.C.: Association of Concerned African Scholars Publ.

Kennedy Boudali, L. (2007). The Trans-Sahara counterterrorism partnership (p. 8). New York: The Combating Terrorism Center, United States Military Academy West Point Publ. Retrieved from http://ctc.usma.edu

Pecoraro, A. (2012). What are the political causes of failed states in Sub-Saharan Africa. Retrieved from http://www.e-ir.info/ 2012/07/31/what-are-the-political-causes-of-failed-states-in-sub-saharan-africa/

Tomolya, J. (2012). Challenges of terrorism. Art of War (Hadtudomány) MHT Publ., 22(3-4), 34-36. 